\title{
الإيمان والعمران
}

\section{عبد الجيد عمر النجار}

\section{تمهيد}

وجود الله تعالى واتِصافه بصفاته حقيقة ثابتة في الأزل وإلى الأبد، فهي مستقلّة في ثبوتا عن الإنسان نفسه، ولا علاقة لما في وجوده بإيمانه أو عدم إيمانه، بل لا علاقة لما بوجوده هو أو عدم وجوده أصلاً. ولملا كانت هذه الحقيقة كذلك فإنّا إذن تستمدّ قيمتها وقداستها من ذاتا، وذلك بوصفها الحقيقة الأولى من حقائق الوجود كلّها، بل بوصفها مصدر تلك الحقائق جميعاً. وبناء على ذلك فإنّ الإيمان بوجود الله وصفاته هو غاية في ذاته، لأنّه إيمان بأمّ الحقائق؛ وإذا كان الإيمان بالحقيقة يُعدّ فضيلة على إطلاقه، فكيف به إذا كان إيماناً بأمّ الحقائق وجودِ الله تعالى وصفاته؟

إلا أنّ الإيمان بالله لئن كان مطلوباً لذاته بوصفه الحقيقة العليا، فإنّه يطلب أيضاً لما يُحدث في الحياة العمليّة للإنسان من آثار تنعكس عليها بالتوفيق والصّلاح، إذ هو يصبغ هذه الحياة كلها بصبغته، ويضفي عليها من خيريّته ما لا تناله أبداً بدونه، بل إنّا بدونه لا تكون إلا في بوار، وذلك هو مصداق قوله تعالى:

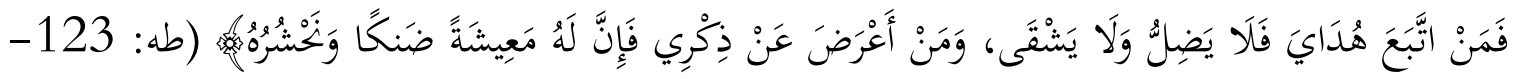

و الله تعالى لمها شرّع للإنسان على رأس الدّين الإيمانَ به وجوداً وصفات، فإنّه في ذلك غنيّ عن أن يناله من إيمان الإنسان شيء، ولكنّه شرّعه له لطفاً به ورحة، كي يعرف الحقّ في ذاته ويفضُل به لأنه فضيلة، ثمّ كي ينتفع به في حياته العملية، إذ هو يفضي إلى السعادة. والإنسان لما يؤمن بالله استجابة لأمره فإنه ينبغي أن يفعل ذلك بغرض الاستجابة للدعوة لكوها قصداً أولاً، لأمره فإنه ينبغي أن يفعل ذلك بغرض الاستجابة

* دكتوراه من جامعة الأزهر 1401هـ/1981م، عمل بجامعات: الزيتونة (تونس)، والأمير عبد القادر للعلوم الإسلامية (الجزائر)، والإمارات العربية المتحدة (العين). متفرغ للتأليف والبحث العلمي. 
للدعوة لكوها قصداً أولاً، وله أن يُتبع هذا القصد الأصلي بقصد تحصيل الفضيلة المتأتية من معرفة الحق، ثم بقصد ابتغاء الخير العملي الذي يترتب على الإيمان بالله، فتلك كلها مقاصد مشروعة في ميزان الإيمان. وإذا كان الإيمان بالله يثمر في الحياة الملية صلاحاً على النحو الذي ذكرنا، فإن العلاقة بين الإيمان وصلاح الحياة تغدو شبيهة بأن تكون علاقة تلازم بين الطرفين، بجيث يكون تحقق الملزوم وهو الإممان مفضياً إلى تحقق اللازم وهو صلاح الحياة، وذلك ما يوفر في سبيل الدعوة إلى الله منهجاً فاعلاً في النفوس، وهو ما يتمثل في الدخول إليها في سبيل التصديق بالله من بيان ما ينشأ عن ذلك التصديق الإيماني من سعادة في الحياة العملية، وذلك من باب الاستدلال باللازم على الملزوم، فيُبتغى الملزوم إذن من طريق ابتغاء اللازم.

وفي نطاق هذا المنهج فإنّ بسط المنافع العملية التي يحدثها الإيمان بالله في الحياة، وإظهارها للناس إظهاراً عيانياً بالشهود، أو إظهاراً استرجاعياً بالتاريخ، أو إظهاراً عقلياً بالتحليل المنطقي، يكون من شأنه أن يهيئ النفوس للإقبال على الله تعالى بالتعمق في معرفته والتصديق به إن كان أصل ذلك حاصلاً، أو بالبحث والتقصي للإيمان به إن لم يكن حاصلاً؛ وذلك لأن المنافع في الحياة العملية لما تلوح للإنسان فإنها تدفع النفس إلى التمسك بأسباجها في سبيل الحصول عليها، سواء كانت تلك الأسباب مادية تلتمس في الواقع الخارجي، أو كانت معنوية تُلتمس في داخل النفس. ولا غرو فإنّ في طبع الإنسان من الحرص على السعادة ما يدفع به إلى الكدّ في البحث عن أسباهما، والحفاظ عليها بعد تحصيلها.

وقد كان هذا المنهج في الدعوة إلى الله منهجاً نبويًاً عاماً، حيث درج الأنبياء في دعوقم أقوامَهم إلى الإيمان بالله على أن يبسطوا لمم حياة المؤمنين فيما يسودها من السعادة، وحياة الكافرين فيما يسودها من الشقاء، حملاً لهم على ابتغاء السعادة وتحاشي الشقاء من طريق الإيمان بالله، وفي هذا المعنى يندرج القصص القرآي الذي اهتم بعرض حياة الأمم وما أدّى إليه الإيمان فيها من فلاح وي مقابل ما أدّى إليه الكفران من بوار، وفي هذا المعنى أيضاً يندرج الخطاب القرآني في تذكيره الناس بما ثريت به حياقم من الخير لما انتقلوا من الكفر إلى الإممان، وتحذيره إياهم من ضنك المعيشة إن هم أعرضوا عن الله، وذلك في مثل قوله تعالى:

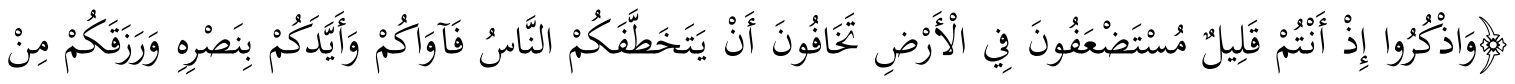

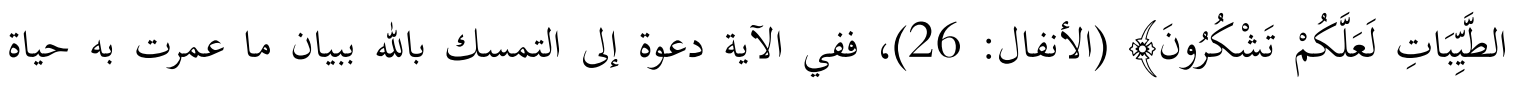


المدعوين من الخير المادي والمعنوي لما عرفوا الله، وفيها تحذير ضمني من النكوص إلى سالف الضنك في حياتم إن هم نسوا ربّمم ونكصوا في إيماغم به.

وإذا كان هذا المنهج في الدعوة إلى الله منهجاً عاماً يصلح لكلّ الأوضاع والأزمان، فإننا نحسب أنه في الظروف والأوضاع الراهنة أكثر صلاحاً وفاعلية في التعريف بالله لمن لا يعرفه، وفي الدّفع إلى أحكام الصلة به لمن عرفه، ولكن اعترى الفتورُ تلك الصلة وآلت عراها إلى الارتخاء، وذلك للأسباب الآتية:

أولاً: ما حدث في هذا العصر من موجة إلحادية عاتية قامت فيما قامت عليه من المسوّات على القول بأن الإيمان بالله من شأنه أن يعطّل طاقات الإنسان عن العمل والإنتاج، كما يعطّله عن البحث العلمي الحقيقي الذي يؤدّي إلى ذلك، وهو ما عبرت عنه العبارة الشهيرة: "الدّين أفيون الشعوب"، مع الاستشهاد في ذلك بما نشأ من حياة التمدّن الرّغيدة قائمةٌ على غيبةٍ من الإممان بالله، وهو ما يغري العقول والنفوس بالاعتقاد أنّ العيش الرغيد في حياة الناس ليس له في حدوثه علاقة سبية بالإيمان إن لم يكن الإيمان سبباً عكسياً في ذلك، وهذه فتنة لا يمكن أن تقاوم إلا بمنهج مضادُّ يبرهن على أنّ رغادة العيش إنما هي رهينة الإيمان بالله.

ثانياً: ما أصبح سائداً في العقلية الغربية وتسربت منه آثار إلى التفكير العام عند سائر الشعوب من نزعة نفعي ترتبط فيها الأفكار في حظوظها من الحقيقة بما تفضي إليه من النفع العملي في الحياة، فيكون إذن المدخلُ إلى الأفكار لتبنيها معتقدات تتصف بالحقية بيان ما تثمره تلك الأفكار في حياة الإنسان من الخير العملي المحقق للسعادة، والفلسفة الذرائعية التي توشك أن تسود العالم اليوم هي فلسفة قائمة على هذا المبدأ كما أصله فلسفيا رائدها الأكبر ويليام جيمسيسئس William James (تويف: 1910م)، وكما جرت عليه الثقافة العملية في العالم الغربي عامة، ويف المجتمع الأمريكي خاصة، وهذا الوضع الفكري يمكن استثماره بنجاعة بهذا المنهج العملي في الدعوة إلى الله.

ثالثاً: ما آل إليه أمر المسلمين من ضعف ضنك وهوان في حياقم العملية، وهو ما من شأنه أن يوقع في نفوس بعضهم أن الإيمان بالله الذي يزعمون أفم متحققون به، لم يغنِ عنهم في ميزان المنفعة العملية شيئاً، قياساً في ذلك على غيرهم ممن لا يؤمنون بالله من الأمم التي تعيش حياة الرفاه والغلبة، وهذه فتنة شديدة 
تغري بالانسلاخ من الإيمان بالله، أو على الأقل بالتحلل من الروابط الواصلة به في مضمار الحياة العامة والإبقاء على الصلة الروحية الخاصة شأناً شخصياً لا علاقة له بالحياة الاجتماعية، وهو ما يحدث اليوم على لى لئل نطاق واسع، متمثلاً في المنزع العلماني الذي فشا في الحياة العملية للمسلمين. وهذا المنهج الذي نطرحه هنا كفيل بمقاومة هذه الفتنة ومحاصرة آثارها.

وبإزاء هذه الأسباب يغدو من المهم جداً في سبيل الإقناع بالله تعالى إقناعاً ابتدائياً، أو إقناعاً بإحكام الصلة به، أن يُخاطب الناسُ من الجاحدين ومن المتهاونين على حد سواء بخطاب برهاني على صلة التلازم بين الإيمان بالله وسعادة الحياة الفردية والاجتماعية فيما يفضي به الأول إلى الثاني، وذلك ببيان ما يثمره

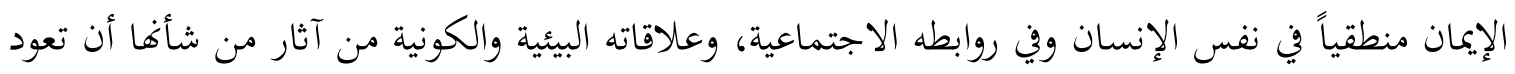
عليه بالسعادة فيها جميعاً، وكذلك ببيان ما أثمره ذلك منها بالفعل في التجربة التاريخية للتحضّر الإسلامي، مقارنة بما يفضي إليه موقف الجحود أو الفتور في العلاقة بالله تعالى، من بوار في نفس الإنسان ذاته، وفي علاقاته بالمجتمع وبالكون: تحليلاً منطقياً، واستشهاداً بما آل إليه الواقع الراهن من أزمات تعانيها الحضارة التي قامت على غير صلة إيمانية بالله تعالى.

وإننا لنحسب أن هذا الخطاب إذا ما كان محكم البيان استدلالاً وتمثلاً ومقارنة فيما توجّه به إلى العقل والوجدان معاً، فإنه سيكون رافداً فاعلاً في تحريك الناس نخو ربهم وتوجيهـم وجهته، وقد يفوق في نجاعته ما جرى عليه الخطاب القائم على الاستدلال العقلي المجرد والاستدلال الكوني كما هو سائد في البيان العقدي المعهود، وذلك نظراً للأسباب التي ذكرناها آنفاً، والتي تحولت بها مداخل الإمعان في الكثير من النفوس من منافذ المجردات العقلية إلى منافذ المنافع العملية، فإن العقول إذا اقتنعت بالمنفعة العملية انتقلت منها إلى أسباهما المجردة لتقتنع بها أيضاً، من حيث كانت عقلية الأمس تقتنع بالنظر لتنتقل منه إلى العمل. وتلك تحولات في التفكير الإنساني تطرأ عند التحولات الثقافية الكبرى في التاريخ، ومن أمثلته البارزة ما 
حدث بالدعوة الإسلامية من تغير فكري اتجهت به العقول في ابتغاء الحق إلى الانطلاق من العالم المسوس بعدما كانت تتجه في ذلك من التأمل المجرد في الثقافة الهلينية التي كانت سائدة في عالم الفكر. 1 وإنه لمن الحكمة أن يُخاطب الناس في سبيل إقناعهم بالله تعالى وتقوية صلتهم به بالوجه الذي منه يقتنعون، وأن يُدخل إليهم من الباب الذي عبره ينفتحون، وأن يتغير لونُ الخطاب ووجهةُ الدخول بتغير الأوجه والمداخل حسب الملابسات والأوضاع. واعتباراً بهذه الحكمة وانفعالاً بها، فإننا عمدنا في هذا البحث إلى أن نفصّل البيان في وجوه الآثار العملية التي تحصل في حياة الإنسان فتعمرها بالخير والسعادة على صعيد الكيان الفردي، وعلى صعيد الرابطة الاجتماعية، وذلك حينما يرتبط بالله تعالى حق الارتباط، حاسبين ذلك ضرباً من الاستدلال من شأنه أن يكون مدخلاً يقنع الكثيرين بالتوجه إلى الله للإِمان به أو لإحكام الصلة معه، استكمالاً في ذلك لما هو مقرر من وجوه الخطاب العقدي، ومن أنواع الاستدلالات العقلية المعهودة.

\section{1- 1 أثر الإيمان بالله في تزكية الفرد}

لقد اخترنا التعبير عن الخير العملي الذي يثمره الإيمان بالله بـ "التزكية" لأنه تعبير قرآي يستجمع معاني النمو والخيرية معاً، ولذلك قيل في معنى تزكية النفس: إنه "تنميتها بالخيرات والبركات". 2 وعلى هذا المعنى فإننا نقصد بتزكية الفرد أن الإيمان بالله تعالى من شأنه أن يزكي الإنسان من حيث هو فرد، أي ينمي فيه طاقات الخير والنجاعة، ويطهره من شوائب الشر والكلالة، بما يجعله في حياته على درجة عالية من الاقتدار على تحقيق المصلحة التي هما تكون سعادته. وتشمل هذه التزكية أبعاداً ثلاثة فيه هي: النفس، والفكر، والعمل.

أ- تزكية النفس: نقصد بالنفس هنا معناها الخاص متمثلاً فيما يكون محلاً للأحاسيس والعواطف والنوازع والآمال وغيرها مما هو في معناها، فالنفس بهذا المعنى ينعكس الإيمان بالله تعالى عليها انعكاساً صحياً، إذ يشيع فيها جملة من المعاني تقيها الاضطرابات والاهتزازات التي تفضي بالإنسان إلى الضعف تورس

راجع في ذلك: عمد إقبال: بتحديد التفكير الديني في الإسلام، تربمة عمود عباس (القاهرة: لجنة التأليف والنشر، 1968)، الراغب الأصبهاني (ت: 502هـ/1108م): المفردات، تحقيق صفوان داوودي (دمشق: دار القلم، 1992)، ص381. 
والقلق والحيرة واليأس وغيرها من أمراض، فإذا هو تعيس فيما يشعر، كل فيما يفعل، فيقعده اضطراب النفس عن تحصيل المنافع الممكنة له من القيام بمهامه في الحياة. ومن أوضح المعاني التي تحصل في النفس من الإيمان بالله، وأبرزها تأثير في السلوك نذكر ما يلي:

أولاً: الطمأنينة والأمن: لا شك أن الإنسان يستشعر في نفسه القلّة والضعف إذا ما قايس ذاته بما حوله من موجودات الكون. وإذا كان بعقله يستطيع أن يسخر كثيراً من الموجودات التي تبدو أكبر منه وأقوى، فإنه يقف عاجزاً حيال الكثير مما يقع في الكون من الظواهر الجبارة التي لايملك لها دفعا ولا يستطيع منها حماية. وقد كان هذا الشعور بالضعف يدفع الكثيرين من الناس إلى اتخاذ آلهة من موجودات الكون نفسها، يسعون إلى استرضائها بضروب من القرابين، توهما منهم أها بذلك ترعاهم بحمايتها، وترد عنهم عوادي الطبيعة، ولكن ذلك لم يكن يجديهم من الطمأنينة والأمن شيئاً لما هو مبني عليه من الوهم الذي تهري سرعان ما ينكشف لهم بطلانه بالتجربة الواقعية فلا يزدادون إلا خوفاً وهلعاً.

لكن الإيمان بالله المتصف بالكمال من شأنه أن يشع في نفس المؤمن الطمأنينة والأمن، فإنه به يستقر في الاعتقاد أنّ الكون يملكه قوي جبار، يدبّر أمره بناموس مستقر وفق إرادة خيرة رحيمة بالعباد، وإذن يقرّ في النفس أن الطبيعة لا تتحرك فوضى فتخبط الإنسان بكوارثها خبط عشواء، أو هي تفعل ذلك انتقاماً منه وتنكيلاً به، بل إن كل ما يقع فيها هو بتدبير حكيم رحيم، وحينئذ فإن المؤمن يطمئن إلى أن كل ما يقع في الكون إنما هو بتقدير حكيم، وإنما هو خير وصلاح في جملته وإن بدا بعضه في الظاهر شراً وضرراً.

إن المؤمن قد أسلم قياده في كل أمره لمن اعتقد أنه هو الفاعل الأوحد في الكون، وهو بذلك يكون مطمئن النفس، آمن البال إزاء كل ما يضطرب به الكون من الأحداث، وكل ما تنقلب فيه الحياة من الأحوال، وحاله في ذلك يشبه حال من ركب طائرة معتقداً أنها صُنعت على أدق وأرقى ما يكون التصنيع، وهي قد وُكلت في قيادتا إلى أكفأ القادة وأمهرهم، ألا يكون إذن في رحلته قرير العين آمن النفس؟ وأين منه حال من ركب طائرة لا يعرف من أمر تصنيعها ولا قيادةًا شيئاً، بل لا يعرف أهي موكولة إلى مدبّر عاقل أم

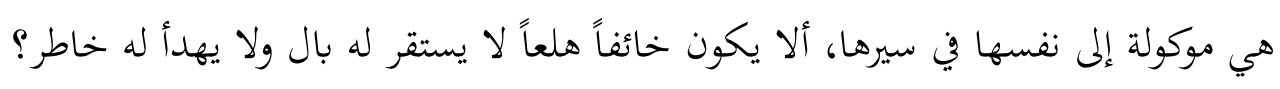


وربما حسب بعض الناس أن الإنسان وإن لم يكن مؤمناً بالله فإنه بعقله قد توصّل إلى اكتشاف قوانين الكون، وعرف أسراره في حركاته وأحداثه، واتخذ من علمه ذاك وسائل للحماية من الطوارئ الفاجعة، فلم يعد إذن يراوده الخوف والقلق بسبب أحداث الكون ومنقلباته، فيكون إذاً قد اعتمد في حماية نفسه بعيداً عن الإيمان بالله، وشاهده الظاهر ما وصل إليه أهل الحضارة الراهنة فيما اكتشفوا من العلم، وفيما اتخذوا من وسائل الاحتماء، وفيما بدا عليهم من نعيم الحياة. ولكن عند التبيّن يظهر أن هذا الحسبان ليس إلا وهما، فالحقيقة القائمة اليوم هي أن أكثر الناس قلقاً وخوفاً في عالم اليوم هم أولئك الملحدون الجاحدون لوجود الله، المعتدّون بعلوم القوانين الكونية معتصماً وحيداً لهم من طارئات الأحداث، فهؤلاء هم الذين ظهرت بينهم فلسفات القلق والعبث مثل الفلسفة الوجودية، وهم الذين تتفشّى فيهم أكبر النسب من الانتحار والجنون والهوس وتعاطي المخدّرات، ${ }^{3}$ وكلها طارئة من الخوف والقلق، وليس النعيم الظاهر عليهم في العيش إلا نعيماً مادياً خارجياً، وأما النفوس فهي تعيش في عالم من الخوف والقلق الدائمين.

وليس من باب الاتفاق أن تظهر في أوربة في منتصف هذا القرن فلسفة القلق والعبث والإحباط التي

نظر لها سارتر Albert camus وألبير كامو ، فهي تعبير عما أصاب الناس من المآسي إثر حربين عالميتين مدمرتين كانتا بوجه من الوجوه ثماراً مرّة لفلسفة الإلحاد التي أعلنت "موت الإله"، وأوكلت قيادة الإنسان إلى عقله حينما اكتشف طرفاً من أسرار الكون وقوانينه، وأصبح قادراً على الاحتماء من غوائل الطبيعة بتلك القوانين كما قرر ذلك أوجيست كومت Auguste Comte في فلسفته الوضعية التي حسبت أن الإنسان قد بتحاوز المرحلة الميتافيزيقية وارتقى إلى المرحلة الوضعية التي يقود فيها نفسه بعقله. ${ }^{4}$ إن حصاد ذلك الإعلان لم يكن إلا كابوساً أشقى النفوس خوفاً وهلعاً وقلقاً وإحباطاً. وقد جاء القرآن الكريم يبين في مضمار الدعوة إلى الله ما يكون لهذا الإيمان من أثر في زرع الطمأنينة والأمن فينفس المؤمن، وذلك في مثل قوله تعالى:

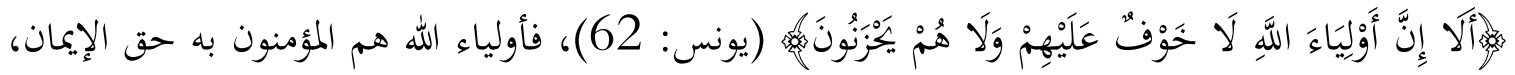
الموحدون له حق التوحيد، والذاكرون له هم الذين يعمرون قلوبهم الإيمان به، ويفيض إيماهم ذلك على

$$
3 \text { } 3
$$


ألسنتهم وجوارحهم، وهؤلاء جميعاً يحصدون من إماهمم بالله الطمأنينة والأمن، وينتفي عنهم كل حزن وخوف. 5 وهذا المعنى هو المقصود بقوله صلى الله عليه وسلم في أولئك الذين جعلوا الله تعالى محور عواطفهم فتحابوا فيه خالصين من علائق الدنيا: "إن وجوههم لنور، وإفم لعى نور، لا يخافون إذا خاف الناس، ولا يجزنون إذا حزن الناس"،6 وهو المقصود أيضاً بقوله صلى الله عليه وسلم في المؤمن بالله حق الإيمان: "عجباً لأمر المؤمن، إن أمره كله خير، وليس ذلك لأحد إلا للمؤمن، إن أصابته سراء شكر، وإن أصابته ضراء صبر". 7 فالمؤمن بالله لا تزعزع نفسه الأحداث مهما كان فيها من شدة، إذ هو يلجأ فيها إلى الله، فتتحول قسوتا بذلك اللجوء إلى خير يشيع في نفسه الأمن والرضا، ويبعد عنه الفزع والحزن.

ولا يخفى أن شعور الإنسان بالأمن والطمأنينة في الحياة هو الشرط الضروري لكي يقدم على العمل والإنتاج والتعمير في الأرض، ففي مناخ الأمن النفسي تنمو القدرات الذهنية وتتجه نخو الإبداع، وتنشط القدرات الإنجازية وتتضاعف فعاليتها ويزكو إنتاجها. وأما إذا سُكنت النفس بالحزن والفزع فإن كل طاقاتا وقدراةما تنكمش عن النمو، وتضعف في الأداء، وتنكفئ النفس على ذاتها منشغلة بما أصابها مقتصرة عليه فلا يبقى لها مجال لأن تمتد بآمالها إلى التعمير؛ ولذا المعنى تحرص الأمم أول ما تحرص على توفير الأمن للناس إذ هو أول شرط لا زم من شروط النهوض العمراني.

ثانياً - العزّة والقوة: إن النفس يصيبها الوهن والمذلة بما يتسلط على الإنسان من أسباب القهر والاستبداد، سواء كانت هذه الأسباب داخلية مثل الموى والشهوات التي تخضع الإرادة وتذها، فإذا هي مطواعة لها، توردها موارد الصغار والريبة، أو كانت أسباباً خارجية مثل الطغيان من الحكام والسلاطين والمستبدين من ذوي الجاه والثروة، والمتسلطين من الكهان ورجال الدين، فهؤلاء جميعاً يخضعون الرقاب

ذهب أكثر المفسرين إلى أن انتفاء الحزن والخوف عن أولياء الله مقصور على الآخرة، وأوردوا على ذلك الأدلّة؛ راجع، فخر الدين النها

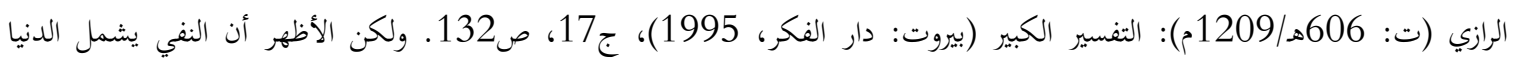

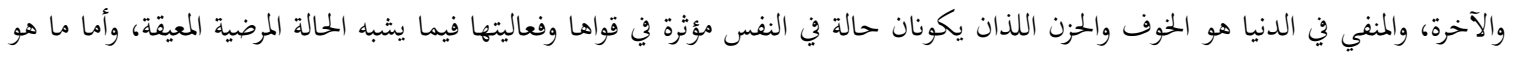

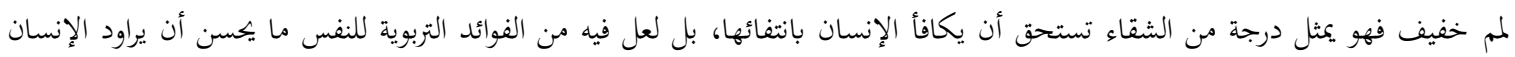

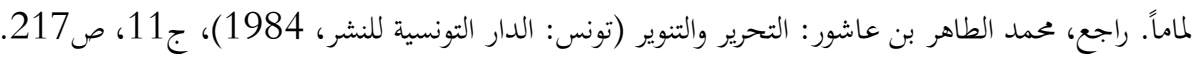

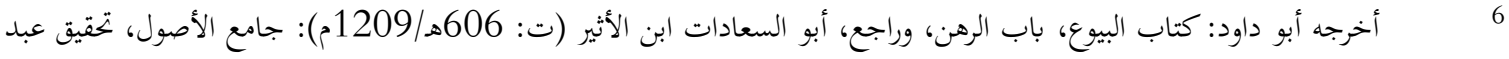

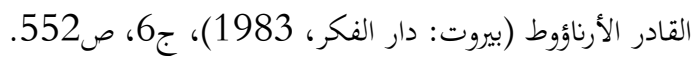
7 
لإرادتم، فإذا الشخص الواقع تحت تأثيرهم مصادرةٌ حريته في التفكير والتعبير، مسلوبة مشيئته في الحركة والفعل، فيورثه ذلك ضعفاً في نفسه، ووهناً في إرادته، وانكساراً ومذلة يستشعرهما في وجدانه، يوجهان كل أقواله وأعماله في أحوال حياته كافة.

ولكن المؤمن بالله، المتحقق بتوحيده التوحيد الأكمل، يكون مسلماً نفسه لله وحده فيما يأمر وينهى، وفيما يشاء ويمنع، وذلك ما يورث فيه تحرراً كاملاً من تلك الأسباب المتسلطة عليه، المكبلة لإرادته، فإذا هو يستشعر في ذاته عزة وقوة بجعلانه ينأى بنفسه عن كل متسلط داخلي أو خارجي، بل بتعلانه ينظر إليهم نظرة استعلاء عليهم واستصغار لهم تحفز في نفسه النزوع إلى المقاومة والجهاد ليقطع الطريق دون كل مستبد، وإنه ليتحمل في ذلك من الشدائد والمحن ما يفضي به أحياناً إلى الموت استشهاداً في سبيل أن يكون مخلص العبودية لله وحده، متحرراً من كل مذلة لسواه.

ولنا أن نتصور مبلغ العزة والقوة اللذين يشيعهما الإيمان بالله في النفس في قصة عمر بن الخطاب رضي الله عنه عند هجرته إلى المدينة، فقد امتلأ قلبه بالله تعالى فاعتز به وحده، ووجد في نفسه من القوة ما تحدّى به المستبدين من قريش، أولئك الذين كانوا يتسلطون على المؤمنين في مكة، ويصادرون حريتهم في الاعتقاد، وفي التعبير ويف الهجرة، ويستذلوفم بأنواع من الاستذلال شتى. إنه في هذا المناخ الاستبدادي الضارب، لما همّ بالهجرة تقلّد سيفه، وتقلّد قوسه، واختصر عنزته، ومضى قِبل الكعبة والملأ من قريش بفنائها، فطاف في البيت سبعاً، ثم أتى المقام فصلى، ثم وقف على الحِلق واحدة واحدة يقول لهم شاهت الوجوه، لا يرغم الله إلا هذه المعاطس، من أراد أن يثكل أمه، أو ييتم ولده، أو يرمل زوجته فليلحقني وراء هذا الوادي. 8 ولقد كان يسع عمر رضي الله عنه أن يهاجر دون هذا التحدّي فيغادر إلى المدينة خفية، ولكنّها القوة التي استشعرها في نفسه اعتزازاً بالله أبت ألا تورده هذا الموقف، استعلاء على الطغاة المستبدين، وإظهاراً للعزة القائمة في نفسه.

وليس لهذه القوة التي يستشعرها المؤمن في نفسه أن تؤول به إلى الاستعلاء على العباد والتكبر عليهم، بل على العكس من ذلك، فإن المؤمن كما يكون مستعلياً على أسباب الاستبداد وأهل الطغيان فإنه يكون

$$
8 \text { إجع: ابن الأثير الجزري: أسد الغابة، ج4، ص152. }
$$


مُوطأ لعامة الناس، متواضعاً لمه، وذلك لأن كل نزوع منه إلى التكبر يدمغه في نفسه استشعاره لقوة الله تعالى

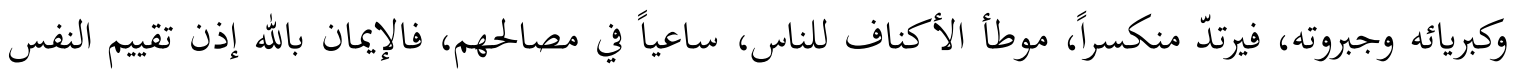
على معادلة دقيقة من استشعار العزة والقوة من جهة، احتماءً بالله وانتصاراً به، واستشعار القلة والضعف بإزاء قوة الله من جهة أخرى، وذلك حينما تراوده نوازع التكبر، فيكون منه التواضع واللين في معاملة الناس.9 9 ولا يخفى أن استشعار الإنسان للقوة والعزة يعود عليه بخير عملي عميم، مهما حمله أحياناً من تبعات جسام؛ ذلك لأن استشعار القوة النفسية يدفع إلى المبادرة والفعل والإنجاز، وهل الإنجاز الحضاري الذي تم على أيدي المسلمين في وقت قصير جداً من ظهور الإسلام إلا أثر لإيماهم بالله الذي حررهم من أصناف العبودية، وآمنهم من ضورب الخوف، فانطلقوا في عزة وقوة يصنعون المعجزات الحضارية في كل مجال، وذلك

$$
\text { بما تقوّمت به نفوسهم من مبادرات ابتكارية، وفعالية إنجازية لا تكون إلا من قوي عزيز؟ }
$$

وال

عمران: 139)، فالإيمان بالله يثمر في النفس شعوراً بالاستعلاء، والمتحقق به خير تحقق لا يداخله الوهن

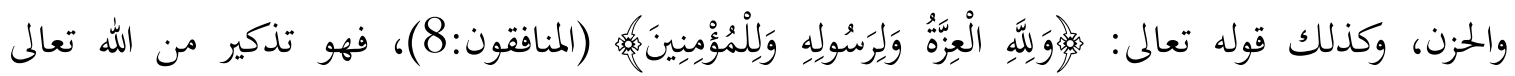
للمسلمين في سبيل المضيّ في إنجاز مهمتهم التعميرية بأن إيماغم بالله هو الذي يمدهم بالقوة والعزة ليتموا ذلك الإنجاز، وهو في الآن نفسه تحذير من الوقوع في الوهن والحزن المعيقين للإنجاز بما عسى أن يتسرب من ضعف في الإيمان. وفي سبيل الإشعار بقوة النفس وعزما قال صلى الله عليه وسلم مبيناً ما يولده الاعتصام بالله تعالى وحده منها: "... واعلم أن الأمة لو اجتمعت على أن ينفعوك بشيء، لم ينفعوك إلا بشيء قد كتبه الله لك، وإن اجتمعوا على أن يضروك بشيء، لم يضروك إلى بشيء قد كتبه الله عليك"، 10 فهذا توجيه إلى المضي قدماً في العمل النافع دون خشية من العباد؛ إذ الضار والنافع هو الله وحده، فلا مسوّغ للإحجام خوفاً من غيره.

$$
\begin{aligned}
& 9 \\
& 10
\end{aligned}
$$


وفي مقابل ذلك فإن النفس حينما تنسلخ من حبل الله تعالى، وتقع في ربقة غيره من المستبدين،فإنها بما تذِل به إليهم يشيع فيها الشعور بالصّغار، فتنقمع ويصيبها الخمول على نحو ما وصفه الكواكبي في قوله: "... أما أسير الاستبداد فيعيش خاملاً خامداً، حائراً لا يدري كيف يميت ساعاته وأوقاته، ويدرج أيامه وأعواهه". 11 بل إن الوضع النفسي نتيجة لذلك قد يتطور إلى ما هو أسوأ، حتى يصير انتكاساً مرضياً تطلب به النفس خلاف ما جبلت عليه من طلب أفضل من الأحوال، والسعي في تحصيل وسائلها، فإذا هي توي إلى طلب الأوضع والرضا بالأدون، قصوراً عن تحصيل الأسباب، وخمولاً دوغا، وهو ما وصفه الكواكبي أيضاً بقوله: "قد يبلغ فعل الاستبداد بالأمة أن يحوّل ميلها الطبيعي من طلب الترقي إلى طلب التسفّل، بحيث لو دُفعت إلى الرفعة لأبت و تألمت كما يتألم الأجهر من النور". 12 ولا فرق في هذه النتيجة بين أن تكون النفس سكس راضية بهذه الاستكانة لغير الله، أو تكون مكرهة عليها بوجه من وجوه الظلم، فإنها في كلا الحالين تنكمش عن الأداء في التعمير، وتسقط في العطالة على نحو ما قرره ابن خلدون في وصفه لأثر الظلم والاستبداد في النفوس إذ يقول: "اعلم أن العدوان على الناس في أموالهم ذاهب بآماهم في تحصيلها واكتساهما لما يرونه حينئذ من أن غايتها ومصيرها انتهايُما من أيديهم. وإذا ذهبت آمالهم في اكتسابها وتحصيلها انقبضت أيديهم عن السعي في ذلك". 13 فالنفس إذا ما انقمعت بغير سلطان الله تعالى على أيّ وضع كان انقماعها، آلت قواها إلى الضعف والهوان، فأصابتها الكلالة في العزائم والأفعال، وانتهت إلى النكوص عن التعمير.14 ثالثاً - وحدة النفس: قد تتوارد على نفس الإنسان مطالب في الأمر والنهي، أو في الترغيب والترهيب، متعددة المصادر، مختلفة الجهات، فإذا بالأوامر والنواهي والرغباء والرهباء تتعارض فيما بينها لتعارض مصادرها، وذلك من شأنه أن يمزق قوى النفس ويشتتها؛ إذ يجعلها تتوزّع بين ولاءات شتى تروم أن تستجيب لها كلها بحك الفرض أو بحكم الاختيار، ولكنها لا تلبث أن تسقط في الحيرة بين النّداءات

$$
\begin{aligned}
& 11 \\
& 12
\end{aligned}
$$

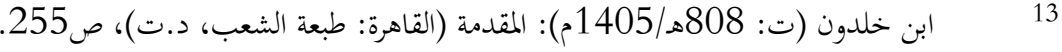

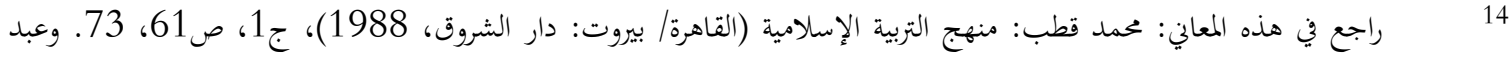

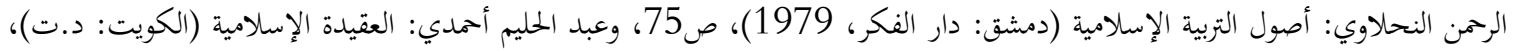


المتعارضة، ويصيبها الاضطراب والاختلال في قواها التي تقوم هما، فإذا هو إحجام وإقدام، وعزم ونكوص، وتقلّب في المواقف ذات اليمين وذات الشمال، وإذا هي عطالة عن الفعل والإنجاز تحاكي عطالة جسم عن الحركة تجاذبته قوى متعارضة من جهات متعددة.

ولنا أن نتبين هذا المعنى من التشتت النفسي فيما هو ظاهر اليوم في أحوال الكثير من المسلمين ممن لم يتحققوا بوحدانية الله تعالى على الوجه الأكمل، فإذا هم مع انتمائهم الوراثي للإسلام حيث يخضعون بالولاء لله في بعض شؤون حياتم يخضعون بالولاء أيضاً لقيم ثقافية غريبة تحكم كثيراً من شؤوهم في الحياة الاجتماعية خاصة. وقد أدّى بكم هذا الوضع إلى تناقض في النفس وتشتت فيها لتوزعها في الانتماء بين مصدر إلهي ومصدر وضعي، فإذا هي تراوح مكاها، فلا هي مضت في طريق الله تبني حضارة إلهية خالفاً عن سالف، ولا هي مضت في طريق أهل الغرب تضاهيهم في بناء حضارة مادية، وتلك هي العطالة الناشئة من تشتت النفس.

وقد صوّر الشيخ محمد الفاضل بن عاشور هذا التشتت الواقع في نفوس المسلمين بين ولاء للعقيدة من جهة، وخضوع لما يجري به الواقع على خلافها من جهة أخرى، والآثار النفسية الناشئة من ذلك معطلة للمبادرة إلى الفعل الحضاري، فقال: "إن الإرادة الإعتقادية البناءة هي التي خارت وضعفت فأصبحت الأوضاع الاجتماعية والآثار المدنية تصدر عن غير ماكانت تصدر عنه (من داعية العقيدة) فصارت هي في واد، والعقيدة الدينية في واد آخر وبقي المسلم وفياً لعقيدته الدينية من جهة، متقبلاً لحياته العملية مطمئناً إلى واقعها من جهة أخرى، حتى أصبح المبدأ النظري والواقع العملي عنه متباينين فسقطت في نفسه منزلة الحياة العملية التي يجياها باعتبار أها مباينة لدينه الكريم، يتلقاها تلقي المستهتر، يعرف اشر ويعيش فيه، فهانت نفسه أيضاً في نظره، لأهما تعيش أسيرة لحياة الشر... وتولّدت عن ذلك العقدة النفسية الخطيرة، عقدة الشعور بالنقص الذاتي، وعقدة اليأس من استقامة الحقيقة الدينية". 15 إنّ هذه الأمراض والعقد النفسية المعطلة للإنتاج ليست إلى نتيجة لإيمان بالله مهزوز، غير قائم على خلوص الوحدانية، فإذا الولاء موزّع بين أوامر الله وسطوة الواقع، ومن ذلك كان داء التشتت المذهب للمبادرة في الابتكار، والفاعلية في السلوك. 
وفي مقابل ذلك فإنّ المؤمن بالله حق الإيمان، الموحّد له حق التوحيد، تكون نفسه إلا موحدة القوى، منسجمة الأطراف؛ وذلك لأغا لا تدين بالولاء إلا لجهة واحدة هي جهة الأمر الإلهي، فالله وحده هو

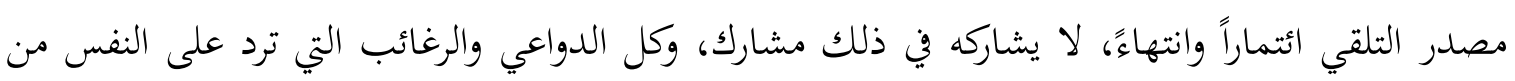
داخلها أو من خارجها تردّ إلى الداعي الإلهي ليكون عليها حكماً يقرّ فيدرج فيه، ويُلغي منها ما يلغي فتنقطع علائقه بالنفس وكذلك فإن الله وحده هو الوجهة التي يُمّمها الإنسان، ولا سبيل إليه بيّنة لا تتردد فيها النفس ولا تتيه. فوحدة المصدر من جهة، ووحدة الوجهة من جهة أخرى، تورّثان وحدة في النفس، تتآلف فيها قواها في غير ما خلل واضطراب، وتنطلق في طريق العمل بفعالية عالية وبطاقة إنجازية رفيعة، بهما تحققت حضارة التوحيد بتصميم من نفوس الموحّدين على نحو ما وصف ابن عاشور قائلاً: "باليقين الديني أقدم (الجمتمع الإسلامي) على تكوين الأوضاع العالمية في صورتا التطبيقية على ما ينبغي أن تكون عليه، وعلى نحو ما يناسب رجوعها كلها إلى الحقيقة الخلقية الإلهية التي أدركها، واعتزّ بأنه أحسن إدراكها وأحسن إدراك الأشياء بحسن إدراكها، فالحقيقة الاعتقادية الإلهية حينئذ هي الأساس لكلّ ما بنت الحضارة الإسلامية من هياكل حسيّية ومعنوية". 16 وقد ضُرب في القرآن الكريم مثل بليغ لبيان الوحدة النفسية للموّدين في مقابل التشتت النفسي عند المشركين، وذلك في قوله تعالى:

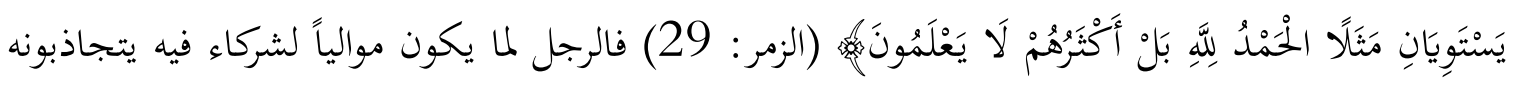
بالأمر والنهي وهم مختلفون، فإنه يكون منقسم النفس بينهم، فتنتابه الحيرة والاضطراب، ولكن حينما يكون الرجل يُختصاً بخدمة رجل واحد فإنه يتجه إليه بكليّة نفسه، فلا يكون شتاتاً مثل الأول، "والمراد تمثيل حال من يثبت آلة شتى، وما يلزمه على قضية مذهبه من أن يدعي كل واحد منهم عبوديته ويتشاكسوا في ذلك ويتغالبوا كما قال تعالى: أيّهم يعبد، وعلى ربوبية أيّهم يعتمد، ومن يطلب رزقه، ومن يلتمس رفقه، فهمه شعاع (أي متفرّق) وقلبه 
أوزاع، وحال من لم يثبت إلا إلهاً واحداً، فهو قائم بما كلّفه، عارف بما أرضاه وما أسخطه،متفضّل عليه في عاجله، مؤمل للثواب في أجله".

هذه ثلاثة من المعاني التي تزكو بها النفس لما تؤمن بالله تعالى: الأمن والقوة والوحدة، وهي ليس إلا معاني أساسية من ثمرات الإيمان في النفس، وإلا فإن ثماره فيها لا تحصى؛ إذ هو يفيض عليه من الخير ما يعمر كل أركافا، ويقوّم كل أحواها، فإذا الإنسان متوفر على هيئة نفسية من التوازن والاطمئنان والقوة تثبت أقدامه في وجوده المادي والروحي، وتقوّم وضعه في بيئته الحسّية والمعنويّة، وهو ما يجعله على استعداد للانطلاق في الكون لإنجاز الحلافة والتعمير في الأرض، بما تحقق له من الشروط النفسية التي هي المنطلق الأساسي لكلّ عمل إنجازيّ قويم.

وربما اتفق للإنسان أن ينطلق في إنجاز حضاري بغير إيمان بالله، وربما أبدع في ذلك الإنجاز إبداعاً ظاهرياً، يوهم بأنه تم بنفوس قوية عازمة آمنة، مما يضع أقوالنا السابقة موضع الشك؛ إذ ينشأ في الخاطر التساؤل: كيف يكون الإيمان بالله هو الموفّر للشروط النفسية للتعمير على نحو ما وصفنا، والحال أن حضارات مشهودة سادت العالم بإنجازاها، وقد قامت على غير إيمان بالله، ومن بينها الحضارة الغالبة اليوج؟ والجواب أننا لو تفحّصنا أمر هذه الحضارات لوجدنا أن الشروط النفسية التي كانت منطلقاً لإنجازها لم يتم لها اكتمال، فبقيت منقوصة في بعض أركاها، وكان لذلك انعكاس بيّن في طبيعة بنيتها، فإذا هي معيبة من جراء نشوئها على غير إيمان بالله بما حملته في نفسها من بذور الفناء تعمل تحت بهرجها بما يؤول بها إلى

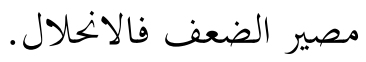

وإذا ما تأملنا في الحضارة السائدة اليوم ربما قيل: إن أهل هذه الحضارة الراهنة بنوا حضارهم على غير إذعان لله تعالى، ولكنهم مع ذلك بنوها بنفوس نزاعة إلى الفعل، قوية في الأداء، نشيطة في التعمير، فكيف كانت كذلك وهي خاوية من الإيمان بالله مصدر القوة والعزّة كما بيّنا آنفاً؟ والجواب أن ما عنيناه بقوة

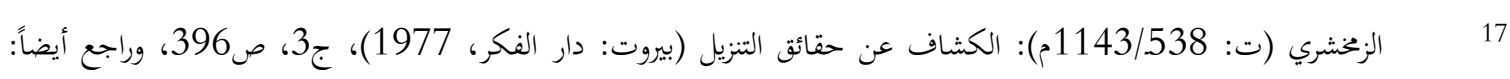

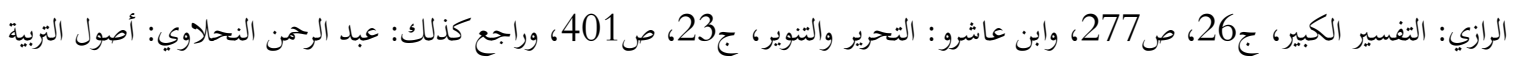


النفس وعزّها المفضية إلى الهمة والنشاط في التعمير إنما هي القوة المفضية إلى التعمير الشامل مادياً وروحياً وأخلاقياً، بحيث تقوى النفس على الاندفاع في الإنتاج المادي زراعة وصناعة ومنشآت وبتهيزات، كما تقوى في الآن نفسه على السعي في الأرض بالرمة والأخوة في نطاق الإنسانية، وبالعدل والمساواة بين الناس، وهذا ضرب من القوة أرقة درجة من الأول وأبعد منه منالاً، ولعل ذلك هو ما أشار إليه النبي صلى الله عليه وسلم في قوله: "ليس الشديد بالصرعة، إنما الشديد الذي يملك نفسه عند الغضب". 18 أما النفس التي أنشأت حضارة اليوم فقد أنشأهما بقوة الصُّرعة حسب التعبير النبوي، أي بالقوة الدافعة إلى التعمير المادي الذي غرضه الأعلى تحقيق الرفاه وإشباع الشهوة، ولكن القوة التي بما يكون العدل والرحمة والأخوة الإنسانية لم تكسب منها تلك النفس شيئاً. وإنه ليمكن القول إن هذه الحضارة ما قامت إلا على الدماء والدموع، وما حركة الاستعمار التي سعت بها أوربة إلى الشعوب الإفريقية والآسيوية لتبيني حضارها على تقتيل النفوس وفب الثروات، وما قامت عليه حضارة أمريكا من إبادة للهنود واستعباد للأفارقة إلا شاهد على ذلك. ولا يعوز مثلُ هذا الشاهد المتتبع اليوم لتصرفات أهل الحضارة الغربية إزاء الآخرين من الشعوب المستضعفة، إذ هي تصرفات تحكمها قوة الصُّرعة لا قوة العدل والرحمة والمحبة.

وفي هذا السياق نفسه فإن حضارة الغرب على الرغم مما وصلت إليه من العتو المادي، إلا أها لما لم تنشأ عن نفوس آمنة مطمئنة بالإيمان، فإن أهلها جعلوا يكدّسون من وسائل الدمار الشامل ما يكفي لتدمير الأرض عدة مرات، وليس ذلك إلا انعكاساً للشعور بالقلق والخوف، فإن الناس إذا فقدوا الاطمئنان سارعوا إلى تصنيع معدات الدفاع وبحميعها، توهماً منهم لما تقققه لهم من الأمن، وهي في حقيقتها ليست إلا تعويضاً نفسياً للأمن المفقود في النفوس، وتلك هي حال أهل الحضارة الراهنة الذين جمعوا من معدات الفناء ما أصبح يُعد نذيراً للإتيان على هذه الحضارة نفسها بالدمار عند أول خطأ بشري أو عبث مستهتر في إدارة هذه المعدات، وهو ما بات اليوم مصدر خوف وقلق يضاف إلى المصدر الأصلي، والكل ناتج عن خواء النفوس من الإيمان بالله. وأين من هذه الحضارة القلقة الفزعة الحضارة الإسلامية التي كانت حضارة العلد والقسط والسلم وحب الخير للعالمين والسعي في نشره بينهم؟ إفا حضارة بناها الإنسان المطمئن الآمن لإيمانه

$$
18
$$


بالله ملاذاً وحيداً وحامياً فريداً. إن حال الوضعين هو ما يصوره قوله تعالى:

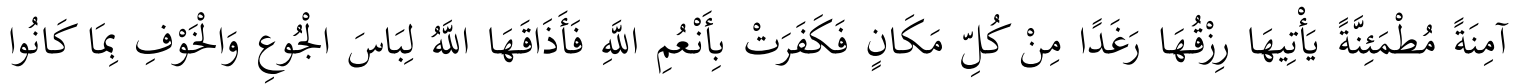
يَصْنَعُونَمَ (النحل: 112)، فهي حال الاطمئنان بالإيمان التي انقلبت بالكفر خوفاً وهلعاً.

ب- تزكية الفكر: نقصد بالفكر طريقة العقل في التفكير لإدراك الحقائق وتدبير شؤون الحياة، فهو كما اصطلح عليه العلماء في التراث الإسلامي: "ترتيب أمور معلومة للتأدي إلى مجهول". 19 ولا شك أن للإيمان بالله تعالى أثراً كبيراً في الطريقة التي يفكر بها العقل؛ ذلك لأن الصورة التي يحملها العقل عن الوجود إيماناً بالغيب أو نكراناً له تشكل حركته في التفكير، وتحدد خصائصه فيه، فذلك التصور هو أهم المعطيات المعرفية الأولية للعقل، وهل طرق التفكير إلا إفراز على نحو من الأنحاء لمعطيات المعرفة الأولية التي تعمر العقل؟ والإيمان بالله في وجوده وفي صفاته يؤثر في العقل من جهة حركته المعرفية تأثيراً إيجابياً ترشد به تلك الحركة في إصابة الحقيقة، وفي توفيق الحياة إلى الخير والصلاح. ولعلّ من أهم مظاهر ذلك التأثير الإيجاب يما يتمثل في الخصائص التالية:

أولا - سعة النظر: ليس من المبالغة القول أن مصير العقل في سعيه إلى اكتشاف الحقيقة محكوم في الإصابة والخطأ إلى حد كبير بمقدار المعطيات التي يتخذها مجالاً للتأمل والنظر، فكلما كانت لتك المعطيات أوسع كانت إصابة الحقيقة أضمن، وبالعكس صحيح؛ وذلك لأن التفكير الذي هو حركة العقل في مادة المعرفة إنما هو بتميع لتلك المادة ومقارنة بينها لاستكشاف الحقيقة من خلالما، فإذا ما تخلّفت بعض عناصر تلك المادة عن أن تكون مناطاً للتجميع والمقارنة تخلّف معها جزء من الحقيقة، فلا يكتشفها العقل، وتكون أحكامه إذن ناقصة، وقد تكون خاطئة بسبب نقص المعطيات الدالة على الحق.

والإيمان بالله تعالى من شأنه أن يوسّع أمام العقل مجال النظر المعرفي إلى أكبر مدى ممكن، فتنفسح له مادة العلم ومعطساته بأكثر ما يمكن أيضاً؛ ذلك لأن الإممان بالله يجعل نظر العقل ينبسط على مدى عالمين

الجرجاني: التعريفات (بيروت: مكتبة لبنان، 1980) ص176، 176، وراجع في معنى الفكر: ابن سينا: الإشارات والتنبيهات، تحقيق

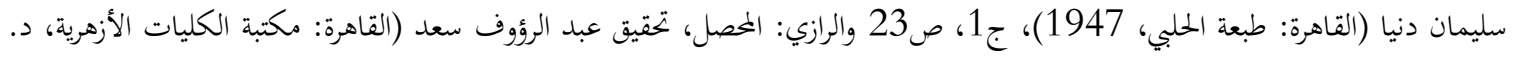

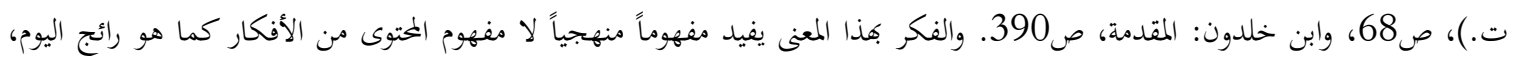
وهذا المفهوم المنهجي هو الذي نعنيه في بحثنا هذا. 
اثنين: عالم مشهود هو عالم الموجودات الكونية، وعالم غيبي هو وجود ما وراء المادة. وإذا ما انبسط نظر العقل على هذا المدى الفسيح فإنه حيئذ سيتجاوز ما هو محسوس إلى ما هو غير محسوس ليتخذ منه مجالاً في تقدير الحقيقة.

وإذا ما اقتصرت حركة الفكر على الجولان فيما هو محسوس فقط من المجودات فإنا حيئذ تسقط معطيات كثيرة من المعطيات المكوّنة للوجود عامة، بل تسقط معطيات كثيرة من معطيات التكوين في نطاق عالم المادة نفسه، فهل في هذا العالم ينخرط كل ما هو موجود بالفعل في نطاق المعلوم بالحس؟ أليس فيه موجودات وتفاعلات واقعية ولكن الحس الإنساني لا يدركها؟ إن الجراثيم الضئيلة، والذرّة ومكوناها لم تكن إلى عهد قريب معلومة للإنسان حتى يتخذ منها عناصر للنظر المعريف، وما يزال كثير من أمثالها في مجال المادة محجوباً عن علم الإنسان، حتى أن الكثيرين من العلماء أصبحوا لا يميزون حدوداً بين عالم المادة وعالم ما وراء المادة من الغيبيات، 20 فهل الاقتصار على عالم المادة المحسوسة مجالاً للعقل في حركة المعرفة كافٍ ليوصّله إلى لي تقرير الحقيقة؟ - ت ت

لعلّ أبرز جواب على ذلك هو ما آلت إليه المادية الملحدة حينما أدرجت الإنسان مادة للنظر المعريف ضمن المادة الكونية المحسوسة، وطبقت عليه قوانينها في البحث، فقد آلت تلك المادية إلى أفكار وتصورات عن الإنسان لا تمت إلى واقعه الحقيقي بصلة، ذلك الواقع الذي تمتد فيه أبعاد من حقيقة الإنسان غير مادية ولا محسوسة، وقد كانت تلك الأفكار والتصورات المادية عن الإنسان سبباً أفزع الكثير من المفكرين، فهبّوا يعارضوفا بقوة ويقولون: "إن اعتبار الإنسان مجرّد وحدة فيزيائية كيمياوية، وجزء من مادة حية قلّ أن تتميز عن الحيوانات، كل هذا يؤدي إلى موت الإنسان الخلقي، وخنق كل روحانياته وكل أمل فيه، ويؤدي إلى ذلك الشعور الرهيب بالبطلان الكامل". 21

إن إفساح النظر العقلي ليشمل ما هو محسوس وما هو غير محسوس، أدعى إلى الكشف عن الحقيقة، وذلك بوصفه توفيراً لأكثر ما يمكن من معطياتا؛ والإيمان بالله يفتح للفكر هذا المجال الذي يشمل المحسوس

$$
20
$$

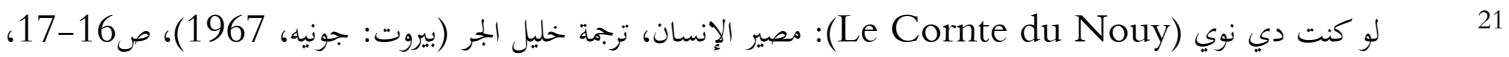
ومّن ساير هذه الوجهة من المفكرين: ألكسيس كاريل (Alexis Carel) في كتابه: الإنسان ذلك الجهول. 
وغير المحسوس معطياتٍ في البحث عن الحقيقة، فالإمان بالله يفسح مادة النظر العقلي في نطاق العالم المحسوس نفسه بما لا ينفسح للنظار من الملحدين؛ وذلك لأن الإيمان بوحدانية الله تعالى كما شرحناه سابقاً يوجه النظر إلى كل ما في الكون من مادة وظواهر وأحداث بوصفها شواهد على الوحدانية، فإذا المؤمن حريص على أن يتقّى آيات الوحدانية الإلهية في كل شيء، مهما بدا في الظاهر عظيماً أو حقيراً، وإذا هو يتوفر بذلك على أكبر قدر من معطيات المادة تتكشف من خلالها بالتحليل والمقارنة حقائق الكون.

ولنا أن نتبين ذلك جلياً في الفكر الإسلامي كيف أنه بتعاليم القرآن الكريم الموجّهة إلى النظر في آفاق الكون وفي طوايا الأنفس بوصفها آيات على وجود الله وصفاته، كيف أنه اندفع إلى تلك الآيات والطوايا يتقصّاها، ويتخذ منها معرضاً فسيحاً للبحث، فيصل إلى علوم ومعارف في الكون وفي الإنسان كانت المنطلق للحضارة الحديثة. وقد أصبح هذا الشّمول في مادة المعرفة فقهاً منهجياً للفكر الإسلامي، وهو ما ظهر جلياً في تصنيف طاش كبري زاده للعلوم حينما بيّن أن المسلمين بحثوا عن الحقيقة في مستويات وجودها الأربعة، الوجود العيني في الواقع، والوجود الصوري في الذهن، والوجود اللفظي في العبارة، والوجود الخطي في الكتابة، ثم جعل ذلك أساساً في إحصائه للعلوم التي أهاها إلى أكثر من ثلاثمئة علم. 22

وبخاصّية الشمول هذه انتهى التحضّر الإسلامي إلى إبداعات معرفية مشهودة، جمعت بين الإبداع في العلوم الطبيعية والإبداع في العلوم الإنسانية والروحية. وليس استيعاب التراث العلمي والفلسفي القديم ونقله إلى الناس إلى مأثرة إسلامية متأتية بشمول النظر في الفكر الإسلامي. وفي التاريخ القديم كانت الحضارة في اليونان والشرق الأقصى تكاد تقصر مجال النظر في عالم المعقولات والروحانيات، فإذا عطاؤها في عالم الكون المسسوس عطاء جدّ فقير. وكذلك فإن الحضارة الغربية الراهنة تخرج من بجال النظر البعد الغيبي والروحي؛ ولذلك فإن عطاءها الخلقي جاء عطاءً فقيراً. أما القرآن الكريم فإنه جاء يقول للناس:

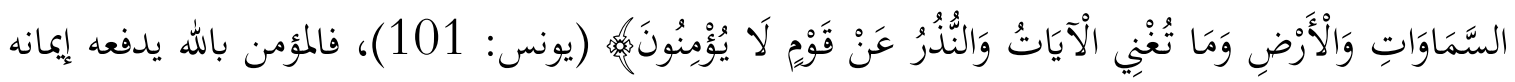

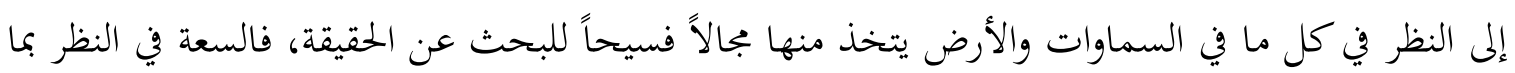
يضمن تحري الحقائق إنما هو إحدى ثمار الإيمان بالله تعالى.

22 20 راجع: طاش كيري زادة (ت: 968هـ/1561م): مفتاح السعادة، تحقيق كامل بكري (القاهرة: دار الكتب الحديثة، 1968)، ج1، ص71. 
ثانياً - تحرر الفكر: قد تتسلط على الفكر أسباب تكبّل انطلاقه في البحث عن الحقيقة، وتعوقه عن التعامل الموضوعي مع مادة المعرفة، فإذا هو يتوجّه بتلك الأسباب وجهة مرسومة سلفاً، ويصل بالتالي إلى أفكار وآراء موضوعة مسبقاً في غير صلة بالحقيقة الموضوعية. وقد تكون تلك الأسباب داخلية من ذات الإنسان مثل الهوى والشهوات التي ترسم نتيجة معينة، وتسوق العقل في طريق يؤدي إليها، صارفة إياه عن مقتضيات الحق في ذاته، وقد تكون أسباباً خارجية مثل العادات والتقاليد الاجتماعية المستحكمة، أو المتسلطين من الطغاة والكهان. وكل هذه الأسباب تضع للعقل نتائج مسبقة، وتوجّهه إليها مقيّدة حركته الحرة في التفكير، تلك التي قد توصله إلى نتائج أخرى مخالفة لتلك النتائج المرسومة. والإيمان بالله تعالى وتوحيده حق التوحيد، من شأنه أن يحرر العقل في حركته الفكرية من كل تلك الأسباب التي ترسم له النتائج المسبقة لتجعله حراً يتعامل مع المعطيات الموضوعية، ويصل من خلالها إلى النتيجة التي تقتضيها تلك المعطيات في ذاتما دون توجيه من جهة خارجة عنها. فالإيمان بالله يحرر الفكر من الهوى والشهوة؛ وذلك لأن التوحيد الخالص يقتضي الانصياع لأوامر الله وحده مخالفة لما يدعو إليه التشهّي من تحقيقٍ للذةٍٍ مادية، أو كسب لمال، أو نصرة لقريب في الباطل، فإن هذه كلها تميل بالإنسان عن مقتضيات الحق، وتدفعه إلى موارد الضلال، ولكن الاعتقاد بوحدانية الله يصد النفس عن ميلها، ويردّه إلى طريق رشيد؛ إذ يرجع الائتمار والانتهاء إلى أوامر الله لا إلى دواعي ميلها، فلا يكون لها إذن سلطان يوجّه الفكر إلى ما تريد هي أن تميل إليه.

وفي القرآن الكريم تقريرات كثيرة لهذه الحقيقة، منها ما جاء في سورة الواقعة من تصوير لحال الكفار المترفين الذين وجّهـم ترفهم لما فيه من سيطرة لأهوائهم وشهواتم إلى التكذيب بحقيقة البعث، إذ هو معارض

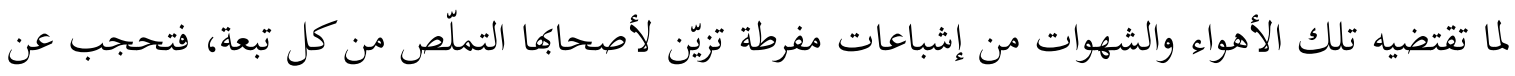
عقولمم حقيقة تبعة الحساب الأخروي، وفي ذلك يقول تعالى :

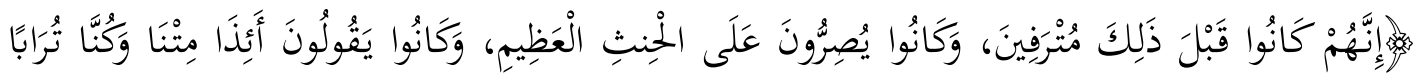

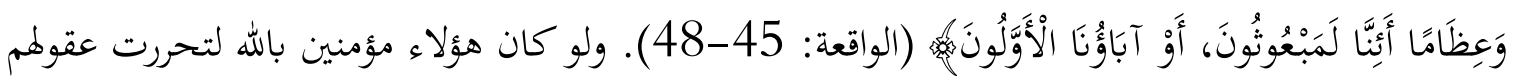
من توجيهات أهوائهم، وتعاملت مع معطيات الواقع من مظاهر الكون لتتبين منها أن البعث أمر ممكن 
بشهادة تلك الظواهر التي يتبدى فيها الخلق من لا شيء، وهو الدليل القاطع على جواز إعادة الأحياء

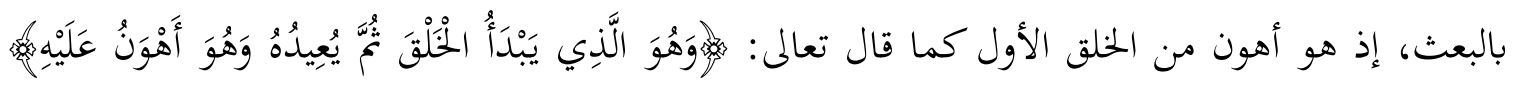

وقد جاء التعقيب القرآني على حال هؤلاء المترفين الذين صرفهم الهوى عن الحق بالتوجيه إلى فكاك عقولهم الغافلة بسبب الهوى، وترويضها على العودة إلى أصل فطرقا الحرة لتتجه حيئذ إلى مشاهد الواقع تتخذ منها منطلقاً في الوصول إلى حقيقة البعث التي أخطأقها بسطوة الهوى، وذلك في قوله تعالى:

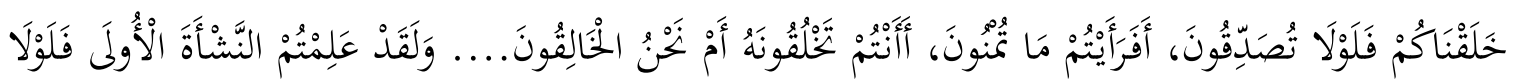
تَذَكَّرونَهُه. (الواقعة: 57-62،59). 23 وقد صوّر الإمام محمد عبده خير تصوير حال من سيطر الهوى على نفسه من دون الله كيف صرفه ذلك عن الحق فقال: "فإذا هم من أنفسهم هامّ بالإصغاء (إلى صوت الحقيقة) دافعوه بما أوتوا من الاختيار في النظر، وانصرفوا عنه، وجعلوا أصابعهم في آذاهم حذر أن يخالط الدليل أذهاغم، فيلزمهم العقيدة، وتتبعها الشريعة، فيُحرموا لذة ما ذاقوا، وما يحبّون أن يتذوقوا، وهو مرض في النفوس والقلوب"، 24 فهو إذن الموى الذي ينسج حجاباً يحجب الفطرة الإيمانية فتغيب عن الوعي. ويحرر الإيمان بالله أيضاً من موروث الخرافات والأساطير التي توجّه العقل إلى تفسيرات وتعليلات لا تمتّ إلى المعطيات الواقعية بصلة، فيقع نتيجة لذلك في الخطأ، وذلك هو شأن آل فرعون الذين فسّروا ما أصاهم من السيئات بخرافة التطيّر فنسبوها إلى شؤم موسى ومن معه عليهم، ولو كانوا مؤمنين بالله لنسبوا ذلك إلى أسبابه الحقيقية التي تخضع لسنن الله في الكون، تلك السنن التي من بينها العلاقة اللازمة بين أفعال

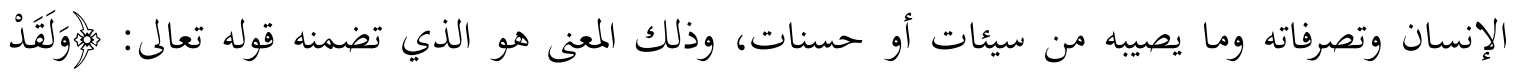

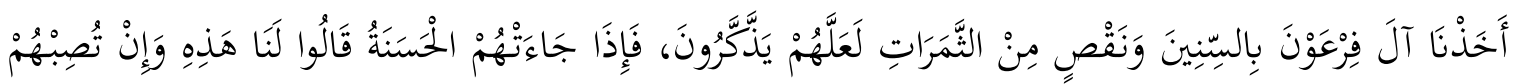

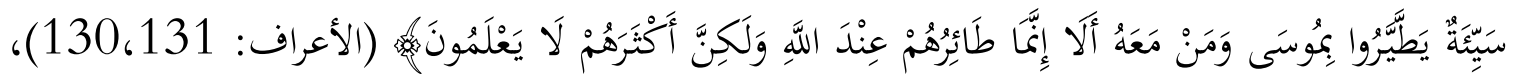
فهؤلاء "لم يعلموا أن سبب المصائب هو كفرهم وإعارضهم... وهذا من العماية في الضلالة، فيبقون منصرفين

$$
\begin{aligned}
& 23 \\
& 24
\end{aligned}
$$


عن معرفة الأسباب الحقيقية، ولذلك كان التطيّر من شعار أهل الشرك؛ لأنه مبنيّ على نسبة المسببات إلى غير أسبا:ها".

كما يهرّر الإيمان بالله من توجيهات الكهنة والطغاة الذين يوجّهون العقول لترى ما يرون هم بحسب

رغائبهم، صرافاً لما عن دلالة المعطيات الواقعية التي تؤدّي إلى الحقيقة؛ وذلك لأن التوحيد يقتضي التسليم لله وحده دون غيره من الوسائط التي تحرّف عنه بالترغيب والترهيب، والتسليم لله وحده يدفع إلى النظر في ملكوته للتعامل الموضوعي مع ما يجري عليه من سنن وقوانين ثابتة ترشد إلى العلم الحق لا إلى الضلال الذي يوجّه إليه الكهان والطغاة.

وقد ضرب القرآن الكريم أمثلة عديدة في تقرير هذا المعنى. ومن بين هذه الأمثلة ما جاء في قصة

فرعون حينما همّ بقتل موسى وجمع الناس ليقنعهم بزعمه إقناعاً تسلطياً يصرفهم فيه عن تلك المعطيات التي

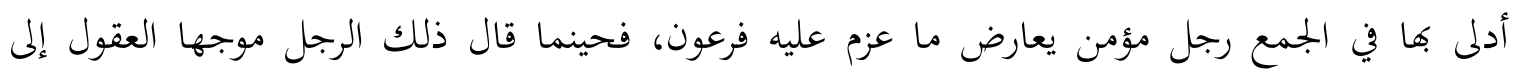

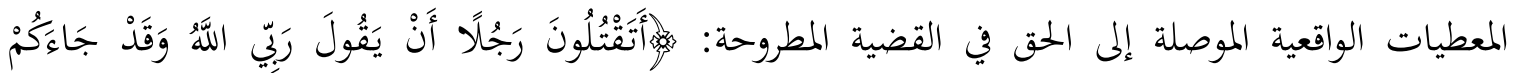

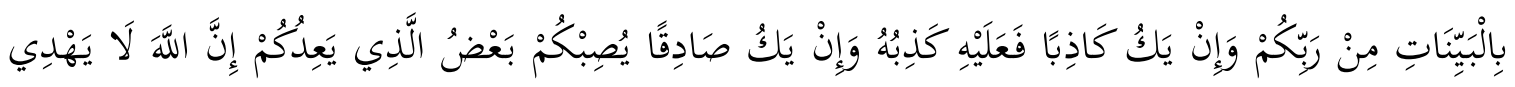

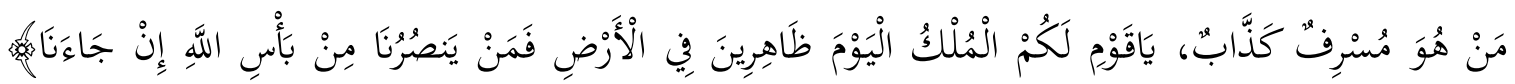

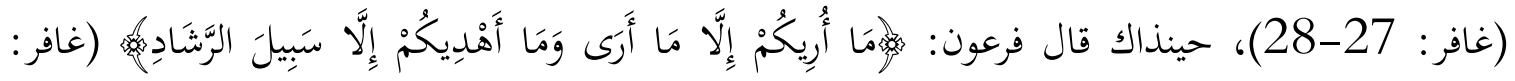
28). وقد كان هذا الحجر الفرعوني على عقول قومه أن يتعاملوا مع معطيات الرجل المؤمن سبباً في ضلال أولئك القوم وهلاكهم، وذلك لصدودهم عن الحق، وأما الرجل المؤمن فقد كان إيمانه يوجّه عقله إلى أن

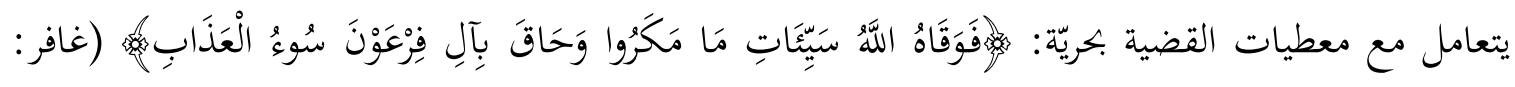

وقد يقال في التعقيب على ما قرّرنا من أن الإيمان بالله يحرر العقل في البحث عن الحقيقة من أن يُوَجه إلى الآراء والأفكار المسبقة، قد يقال: إن الإيمان بالله نفسه يُعد ضرباً من توجيه العقل إلى الآراء المسبقة، تلك التي يمددها الله تعالى بالوحي أمراً وهياً، فقد اقتضى الإيمان إذن ضرباً من التقييد لحرية العقل في

$$
\text { 25 ابن عاشور: تنفير التحرير والتنوير، ج9، ص66. }
$$


التفكير. والجواب على هذا أن الإيمان بالله تعالى يوجّه العقل إلى النظر الحر من كل قيد للتأمل في كشف الحقيقة من المعطيات الموضوعية، ولا أدل على ذلك من أنه يدعو إلى أن يكون موضوع الإيمان نفسه مطروحاُ للتأمل العقلي الحر تدبراً في آيات الكون ومظاهره الواقعية، وأنه لا يعتبر الوصول إلى حقيقة وجود إن الله تعالى وصفاته موفقاً على الوجه الكامل إلا إذا تم بالنظر العقلي الحر الذي يثمر الإيمان عن اقتناع دون تقليد واتباع، فالدعوة الإسلامية إنما جاءت تعرض على الناس حقيقة الإيمان، وجاءت في الوقت نفسه

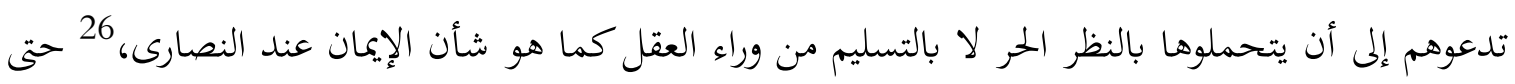
صار ذلك النظر الحر واجباً يتوقف عليه واجب الإيمان، وهو ما قرره المحققون من علماء العقيدة كما ذكره إمام الحرمين أبو المعالي الجويني في قوله: "ذهب المحققون إلى أن (أول) واجب عليه (أي المكلَّف) النظر والاستدلال المؤديان إلى معرفة الصانع". 27 وناهيك بهذا المسلك تحريراً للعقل في نطاق الإيمان بالله تعالى؛ إذ إذ لماكان النظر الحر هو المدخل المطلوب في ذلك الإيمان، فإن كل ما يرد بعد ذلك من حقائق يأتي بها الوحي ويقبلها العقل تكون فرعاً لمذه الحقيقة الأولى، على معنى أن تحملها يكون بالنظر الحر الذي به كان تحمّل سببها الأول. ويمكن القول إن الثمار الحضارية للمسلمين من العلوم والمنجزات المادية والفنية إنما هي ثمار لحرية العقل التي تأتت من الإيمان بالله الواحد، وأنه حينما تغبش الإيمان بالوحدانية في أبعادها الشاملة بتسلط الهوى والطغاة وشيوخ الصوفية الغالية ضاق مجال التحرر العقلي فانحست مكتشفات الحقيقة، وتوسعت الأوهام والضلالات.

وأما ما يرد على الذهن من أن أهل الحضارة الحديثة تحررت عقولمم حتى اكتشفوا الحقائق التي بنوا عليها حضارتم وهم ليسوا مؤمنين بالله على الحقيقة، فجوابه أن أولئك إنما تحررت عقولمم في نطاق معين من التفكير، وهو التفكير في المادة، فوصلوا فيها إلى جانب مقدر من الحقائق، ولكنها ظلت مكبلة في مجال

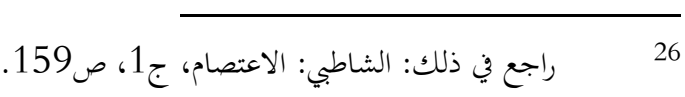

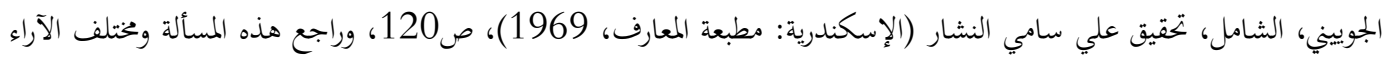

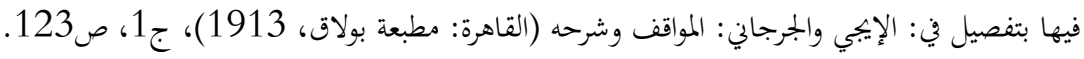

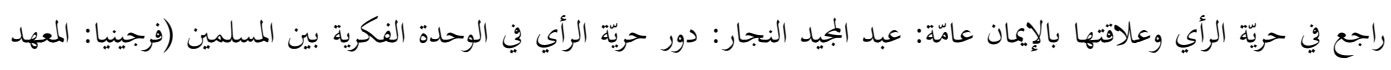

$$
\begin{aligned}
& \text { العلمي للفكر الإسلامي، 1992)، ومحمد يوسف مصطفى: حرية الرأي في الإسلام. }
\end{aligned}
$$


القيم والأخلاق بالأهواء والشهوات ومنازع العالي والتكبّر على شعوب الأرض، فضلّوا فيها الضلال المبين الذي يُرى اليوم في الانحلال الخلقي والجفاف الروحي، وهو المنذر بالدمار لما هو قائم من حضارة المادة كما ذكرناه آنفا، فليست تلك العقول إذن بمتحررة حق التحرر، وإنما هو تحرر منقوص، فأفضى بالعقل إلى الحقيقة في المجال المادي، في حين أبعده عنها في المجالات الخلقية والروحية.

ثالثاً - وحدة المعرفة: من مقتضيات الإيمان بالله تعالى أن يُرى الكون وما يجري فيه من أحداث محكوماً بقانون موحّد، هو قانون الله تعالى وسنته في تدبير الكون. ومن مقتضياته أيضاً أن يُرى الإنسان موحداً في وسائل انفتاحه على هذا الكون ليدرك حقيقته، فالله هو الذي خلق الإنسان في أحسن تقويم ورتب وسائله في الإدراك لتفضي متظاهرة إلى الحقيقة نفسها.

وإذا رئي الكون موحداً في قانون سيره وانقلابه، فإن هذا سيورّث معنى من الوحدة في تفسير الأحداث تُردّ به الكثرة من الظواهر المتنوعة إلى السبب الموحّد، ويتخذ من ذلك مبدأ للفهم تفسر به الأحداث لتعرف حقيقتها. أما لو رُئي الكون وأحداثه شتاتا ينتمي كل قسم منه إلى مدبّر، فإن ذلك يجعل العقل يتيه في معرفة الأسباب الحقيقية التي تحكمه، ويسقط حيئذ في الخرافات والأساطير يفسّر بها أحداث الكون، وقد كانت تلك هي حال فرعون وآله حينما لم يؤمنوا بالله، ولم يدركوا تبعاً لذلك ناموسه في الكون من أن الأقوام على اختلافها في الأزمان إنما يصيبها من الضنك والبؤس بحسب ما تفعل من السوء، وأن ذلك سنة ماضية على اختلاف مظاهرها، ففسروا حيئذ ما أصابها من القحط والسوء بما توهموا من الشؤم الذي جلبه موسى تطيرا به وبدعوته إلى الحق، فأوقعهم شكرهم في ضلال عقولهم عند تفسير الأحداث.

وكذلك إذا رئيت منافذ الإدراك من وحي وعقل وحسّ موحّدة بتدبيرها من قِبل الله الواحد، فإِها حينئ ستكون متساندة في البحث عن الحقيقة يقوم كل منها بوظيفة مكملة للوظيفة التي يقوم بها الآخر، وذلك في غير ما تعارض يُلغى فيه أي منها طريقاً للمعرفة، بل هو التكامل الذي يقوم فيه كل بوظيفة كامل على نحو ما وصف الماتريدي في قوله: "إن محاسن الأشياء ومساويها وما قَبُح من الأفعال وما حَسُن منها،

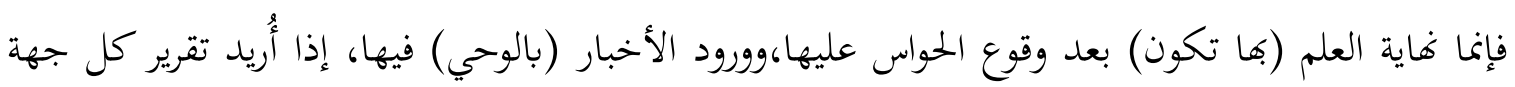


من ذلك في العقول، والكشف عن وجوه ما لا سبيل إلى ذلك إلا بالتأمل والنظر فيها"، 29 فوحدانية الله تعالى حينما تعُر النفوس تصير بها المنافذ إلى معرفة الحقيقة في ذات المؤمن بها موحّدة متكاملة، وتصير بالتالي المعارف الحاصلة بها متآلفة منسجمة، ويؤول الأمر إلى أن يكون "علم الإنسان موحّد المصادر، فالحس والعقل فيما هو مشهود، والبصيرة والوحي فيما هو مغيب، تتحد كلها وتتناصر في رحاب الإيمان، لا يستبد الإنسان بعقله عن وحي يعلّمه مغيبات الأشياء، ولا يستغني بالوحي عن معالجة الكون الظاهر بنظره وتأمله، بل العلم بعضه من بعض، يدعو الوحي لإعمال العقل، ويؤيد العقل مقررات الدين الموحاة، 30 ولعل هذا

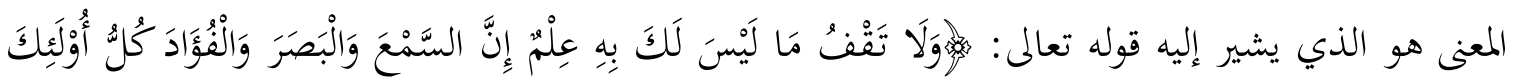
كَانَ عَنْهُ مَسْيُولَا هُهِ (الإسراء: 36)، فالعلم الذي يأتي به الوحي يصدّقه الحس والعقل، فتتم بذلك وحدة المعرفة.

وعلى هذا النّحو من وحدة المعرفة بُنية العلوم الإسلامية كلّها، فبدت على سَعتها وثرائها وتنوّعها وحدة متآلفة يظاهر بعضها بعضاً، ويفضي بعضها إلى بعض، ما كان منها ناشئاً بالخصوصيّة الإسلاميّة، وما كان مُقتبساً من التراث الإنساني، ويستوي في ذلك ما كانت طبيعته سمعيّة وما كان حسّياً أو عقلياً، وما تمّ ذلك إلا بتكوّن الذهنية الإسلامية على مبدأ التوحيد المعرين المتأتي من التوحيد الإيماني الذي سلك قدرات الإنسان المعرفية في خط واحد، وهو ما جعلها تتجه إلى الله الواحد في كل ما تروم من الحقيقة. 31

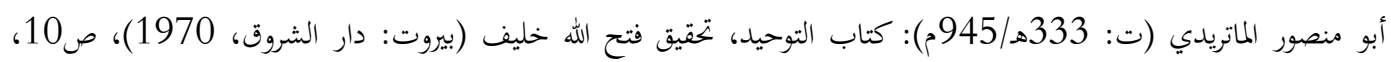

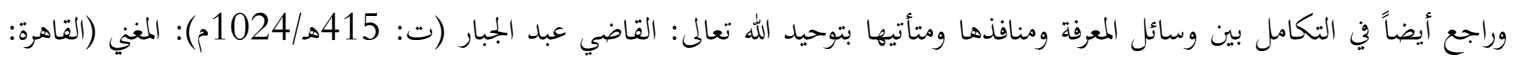

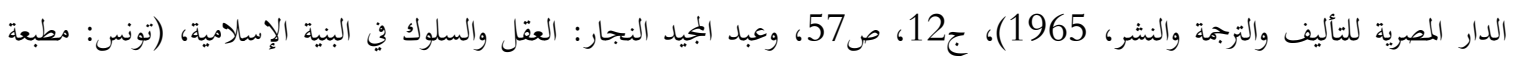

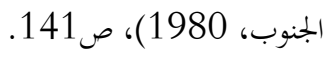
30

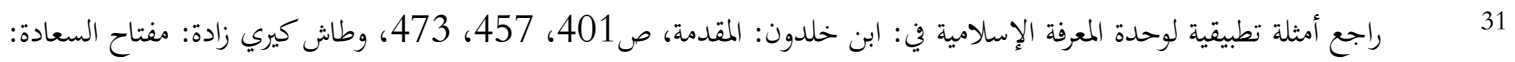

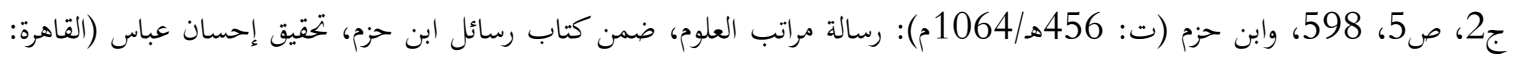

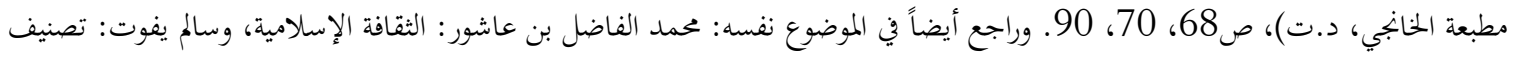

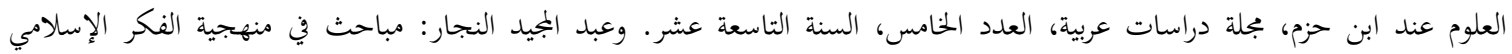

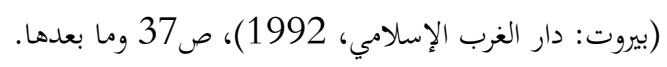


والعقل المشرك لا تتأتّى له هذه الوحدة المعرفية؛ وذلك لأنّه إما يوزّع الأسباب بين الشركاء، فلا ينضبط له قانون في البحث عن الحقائق، فإذا هو ينسب وقائع كونيّة إلى مصدر من معبوداته، وينسب وقائع أخرى إلى مصادر أخرى، وتضيع الحقيقة بين هذا وذاك، وتلك هي حال من تعدّدت آلهتهم فسقطوا في الأوهام والأساطير، أو هو يقتصر على قانون المادّة ناسباً كل فعل إلى المادة نفسها، وعاجزاً بالتالي عن تفسير أيّ حدث لا يرى له سبباً ظاهراً في قوانين المادة، وتلك هي حال الملحدين الذين عجزوا بسبب ذلك عن إدراك حقيقة الإنسان في أبعادها الروحية التي لا تضبطها قوانين الحسّ والعقل، فسقطوا في التشريع له بما يناقض حقيقته في أبعادها المتكاملة، فكان بذلك البوار الذي أسفرت عنه مآلات الأنظمة الشيوعية كما هو ظاهر اليوم. - ماه.

وحينما تكدّرت وحدانية الحكم في التصور الإيماني عند بعض المسلمين فأصبح لهم مصدر من الوحي ومصدر من الوضع في تبيّن حقيقة النّم التي تحكم الحياة، فإِّمّم تناقضت معارفهم في هذا الشأن وتناسخ بعضها مع بعض، وانعكس ذلك سلباً على حياهم التي سادها التذبذب والاضطراب، فظلّلوا بسبب ذلك يراوحون مكاغم في مضمار الفعل الحضاري كما هو مشاهد اليوم للعيان. 32

ج- تزكية العمل: إنّ العمل السلوكي ثثرة للتصوّر النّري؛ ولذلك فهو يتأثر به صحة وفساداً، وانخرافاً وسداداً، والإيمان بالله تعالى يؤثر في سلوك الإنسان تأثيراً بالغاً، سواء من حيث السّداد الخلقي، أو من حيث السّداد النفعي العام. أما من حيث السداد الخلقي، فإن الإيمان بالله تعالى يورّث في النفس استشعاراً للرقابة الدائمة، التي تحصي على الإنسان كل حركة من حركاته، وكل خاطرة من خواطره، إذ الله تعالى يعلم خائنة الأعين وما تخفي الصدور، وهذه الرقابة الإلهية التي يستشعرها المؤمن إذا ما اقترنت بالإيمان بما يترتّب عليها من قِبل الله تعالى من ثواب وعقاب على كل الأعمال، أصبحت مرشداً لتلك الأعمال، وتوجّهها لما فيه الثواب وهي الخيرات منها، وبتنبّها ما فيه العقاب وهي الشّرور والآثام، المنغّصة للحياة الدنيا قبل أن تنغّص الحياة الآخرة.

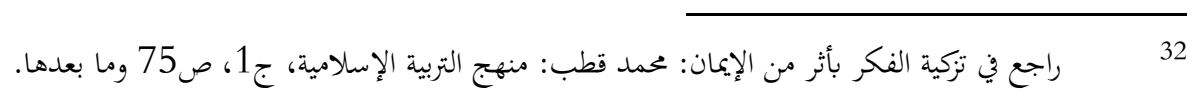


وأمّا من حيث السّداد النفعيّ العام، فإِّ الإيمان بالله من شانه أن يوجّه الأعمال كلّها وجهة موحّدة، هي وجهة الطّاعة لله، فيكون كل عمل صغيراً أو كبيراً، مادياً أو روحياً، مسلوكاً في سلك الطاعة لله، إذ هو الواحد في التعبّد؛ وحيئذ فإنّ أعمال الإنسان ستكون موحّدة لا ينتاهما التشويش والتقسيم بصدور بعضها عن ولاء لجهة ما، وصدور بعضها الآخر عن ولاء لجهة أخرى، على نو ما نراه عند المشركين حينما يتوجّهون بشطر كبير من جهودهم العملية لإرضاء معبوداتم من دون الله، فتكون في حقّ منافعهم الحقيقية هدراً مهدوراً. أما المؤمن فإنّه لا يتجه بأعماله كلها إلا إلى معبوده الواحد، يبغي منها نفعاً في دنياه ونفعاً في أخراه، فيتضاعف إحساها وإتقاها، وتنمو فعاليتها وجدواها.

وليس واقع المسلمين اليوم بحجّة في نقض ما قلناه؛ وذلك لأنّ أعمالمم لا تصدر عن إيمان بالله على وجهه المطلوب، ولكنّ أعمال المسلمين في عصور إيمافم الحقيقي هي الحجّة على أثر الإيمان في تزكية العمل، وذلك حينما ابتهوا بإيمافم الحقّ يصنعون الأعمال في كل مجال من مجالات الحضارة، وغايتهم الله تعالى في كلّ ما يصنعون، فإذا أعمالهم تلك تبلغ من الرّشد والفعالية ما بتحاوز نفعه خاصّة دائرقم إلى محيط البشرية كلّها، وشارة التوحيد ماثلة في كل عمل منها، سواء أكان علماً نظرياً، أو أدبا وفناً، أو إنجازاً صناعياً، أو فناً

وليس ما نراه اليوم من نافع الأعمال في الحضارة المعاصرة بحجّة على أنّ الشرك أو الإلحاد يكون منهما أيضاً ترشيد وتزكية للأعمال، لأنّ ما نراه من العمل النافع في هذه الحضارة إن هو إلا عمل محدود بما هو مادّي، وإلا فإنّ كثيراً مما يصدر عن أهل هذه الحضارة من أعمال في التعامل مع الشعوب ومع البيئة الكونية ليبلغ من الضرّ مبلغاً عظيماً؛ أليست الحركة الاستعمارية وما رافقها من ظلم وطغيان هي التي قام عليها التمدّن الغربي؟ أليس بتميع الترسانة الرهيبة من السلاح النووي، والتلويث المفزع للبيئة الكونية هي من أعمال أهل هذه الحضارة؟ إنّ التزكية الحقيقية للأعمال هي التي تكون بها تلك الأعمال مفضية إلى الخير الشامل للبشرية، وناشرة للطمأنينة والأمن والعدل على الجميع وليست بزكية تلك الأعمال التي توفّر رخاءً مادياً ينعم به بقض الناس، وهو قد صُنع بامتصاص دماء الآخرين، وهدر حقوقهم، والدّوس على كرامتهم 


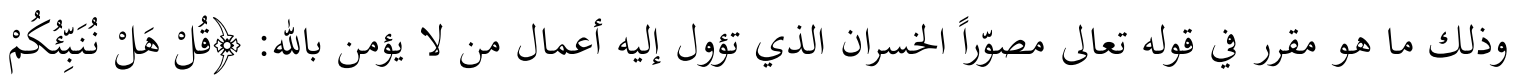

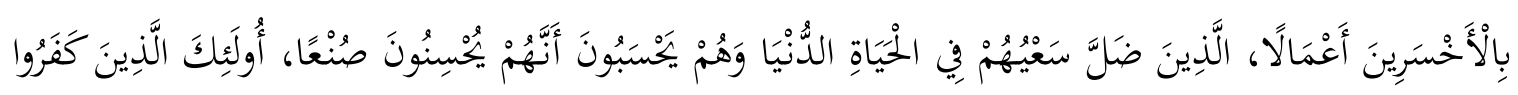

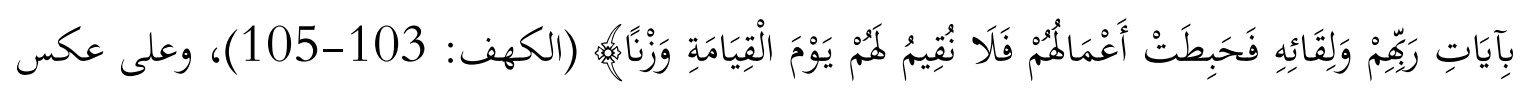
ذلك تكون أعمال المؤمنين بالله تعالى زكيّ' مثمرة في الدنيا والآخرة.

إنّ الإيمان بالله حقّ الإيمان يصوغ كيان الفرد صياغة متميّزة، فيجعله ينمو صعداً في سلّم الخير والإثمار

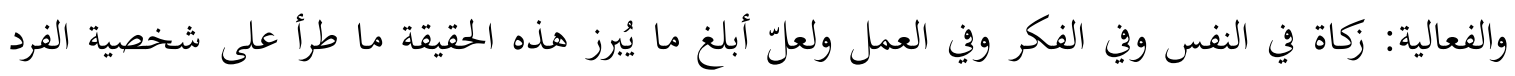

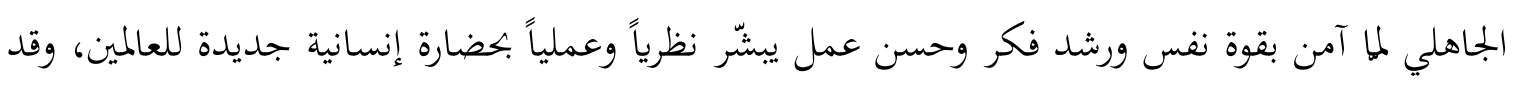

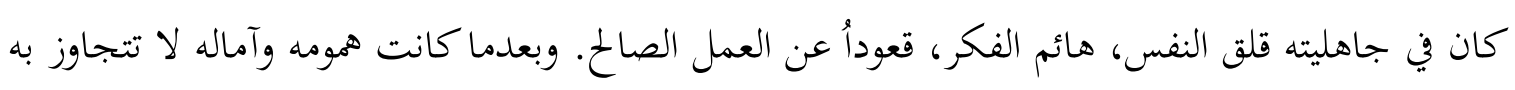

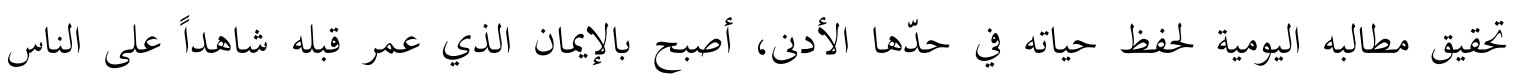

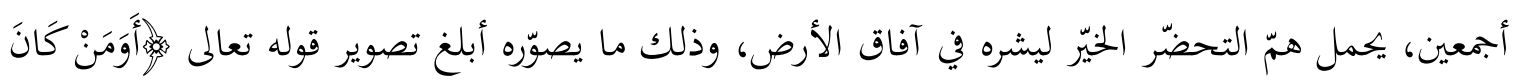

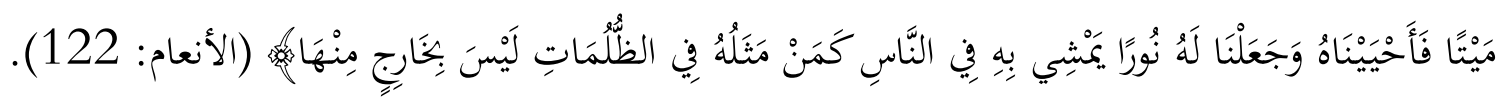

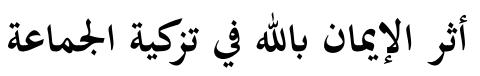

إنّ الإِمان بالله لا يزّي الإنسان في ذاته الفردية فحسب، بل يزّكي فيه أيضاً البعد الجماعي، فيحصل

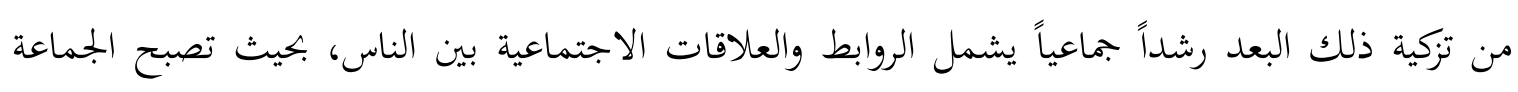

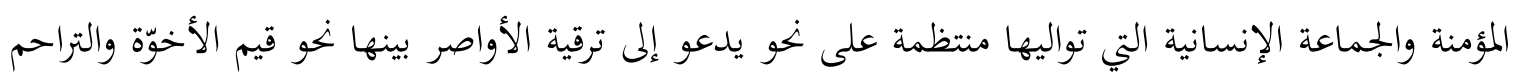

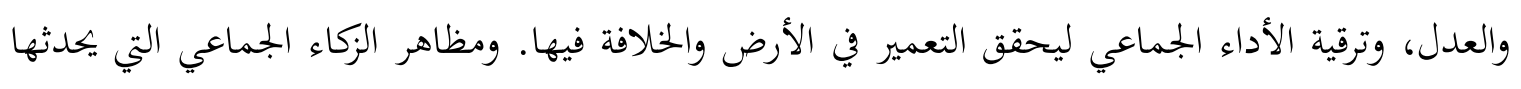

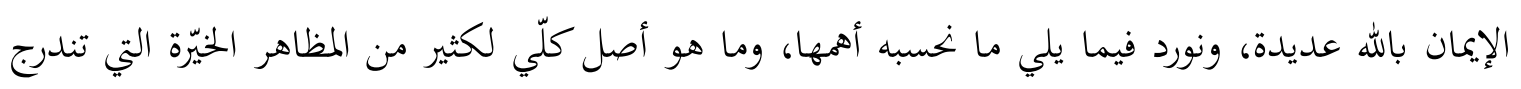

أ- وحدة الجماعة: إن التحقق بوحدانية الله تعالى على الوجه الأكمل، من شأنه أن يؤلّف بين

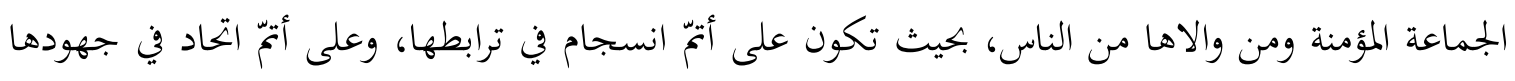

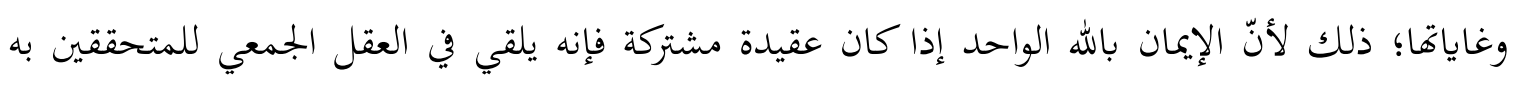


أخلاقاً عامة في الفكر والسلوك تستمدّ من معنى وحدانية الله، ولا تلبث أن تصير سيرة للجماعة المؤمنة تجري عليها حياتا كلها.

ولعلّ من أهمّ المعاني التي تستمدّها الجمماعة المؤمنة من وحدانية الله لتكون لها نسيج وحدة شاملة: وحدة الشعور، ووحدة الولاء، ووحدة الغاية، ووحدة الحكومة. ولو نظرنا في أسباب الفرقة في الجماعات الإنسانية لوجدناها ترجع في أكثرها إلى أخلال تقع في هذه العناصر . ولما كان الإيمان بالله يضمن الوحدة فيها، فإنّ الجماعة المؤمنة تتلافى بذلك أكبر أسباب الفرقة، وتتوفر على أكبر أسباب الوحدة كما نبيّنه تالياً. أولاً - وحدة الشعور: يقتضي الإيمان بالله الإيمان بأن جماعة الإنسان عامة مخلوقة للإله الواحد، وهي مخلوقة من نفس واحدة، فهي واحدة من حيث خالقها، وواحدة من حيث الأصل الذي خلقت منه،

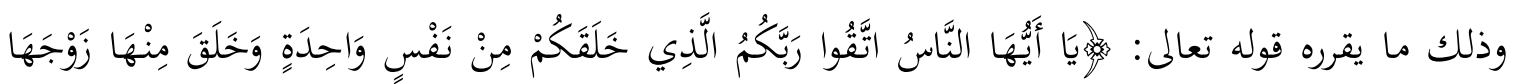

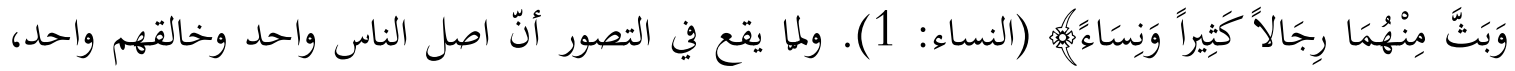
فإن النفوس المؤمنة بذلك تستوي على ووحدة في الشعور بالمساواة في الإنسانية والأخوّة فيها، ويلابسها تبعاً لذلك التسليم التلقائي بمبدأ التكافؤ بين الناس، كما يلابسها الشعور بالتقارب بينهم وتنتفي منها دواعي التمايز والتعالي التي يورثها الإيمان بالاختلاف التفاضلي في أصل الخالق أو في اصل الخلقة، فإذا كلّ يعتز بخالقه أو بأصله الأول، ويكون حيئذ التدابر والتطاحن، وذلك ما يبدو على سبيل المثال في الطبقيّة التي بني عليها المجتمع الهندي، والتي يُرتّب فيها الناس أصنافاً متفاضلة بسبب تفاضلهم في الخلق، فما خلقه في اعتقادهم الإله براهما من رأسه يكون هو الأشرف، وما خلقه مما دون ذلك يكون أحطّ حتى الانتهاء إلى ما يل ئس خلق من الرجلين، وهم طبقة العبيد. إنّ استشعار وحدة المأتى: خالقاً وعنصرً خلق، من شأنه أن يصنع من وشائج الإخاء ما يؤالف بين الناس، وما يفسح من نفوس بعضهم لبعض بالقبول المتبادل وفاءً فطرياً للسبب المشترك الذي منه كان وجودهم، أوليس الأخوة لا يتواشجون بالمبة والتآلف، ولا ينفسح بعضهم لبعض بالقبول إلا وفاء منهم لوحة مأتاهم وهم الآباء؟ فكذلك بالجماعة المؤمنة بالنسبة لوحدة نشأقمم من نفس واحدة وبخالق واحد، فالإيمان

$$
34
$$




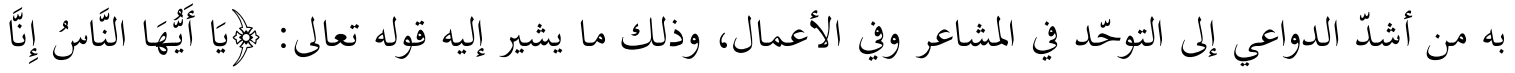

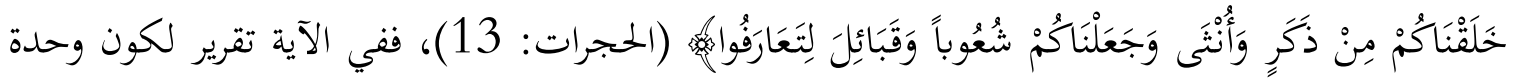
الأصل ووحدانية الخالق مدعاة لأن يكون الناس في معرض كثرقم وتفرّعهم متآلفين موحَّدين متعاونين.

ثانياً - وحدة الولاء: إنّ الإيمان بالله يقتضي أن تكون الجماعة المؤمنة موَّدة في ولائها لجهة واحدة، هي الله تعالى، توجّد إرادةًا جميعاً لمطالبه وأحكامه، وتخضع قيادتما جميعاً له وححد، فلا توزعها جهات متعددة تنفرد كلّ منها بشقّ من الناس يوالوها دون الجهات الأخرى، ويكون حينٔذٍ التدابر والصراع بينها. ألا ترى أولئك الذين اتخذوا من دونه وسائط إليه أو شكوا أن ينزّلوها منزلة الألوهية كيف أفم يوالي كلّ منهم ما اتخذه وسيطاً، صارفاً وجهه عن الموالاة المباشرة لله وحده، فإذا هم يتشاكسون ويتصارعون فتذهب تركب ريحهم، ومن هم من أهل الديانات والمذاهب، ومنهم من هم من المنتسبين إلى الإسلام، ولكنهم غفلوا عن بعض أبعاد التوحيد ومقتضياته، وذلك مثل بعض الفِرق التي والت رؤساءها وزعماءها، ورفعتهم إلى ما يشبه مقام الألوهية بطاعتهم فيما هو مخالف لأمر الله ونواهيه، فكان بينها بسبب من ذلك التفرّق في الولاء الخصام والفرقة ما هو معروف في التاريخ.

ولكنّ الناس على عهد التوحيد الحقيقي في صدر الإسلام، لما انخلعت طوائفهم الكثيرة من ولاء آلتهم

وأصنامهم وعصبياتم، وتوجهوا بالولاء لله الواحد، تبدّل بحافيهم الشديد وتصارعهم المرير إلى وحدة وألفة، فإذا العداوة أخوّة، وإذا التشتّت وحدة، وإذا التحارب تعاون على البر والتقوى، وإذا جماعة المسلمين تضمّ في صف واحد شتاتاً عجيباً من أهل المذاهب والأديان والعصبيات، إها وحدة الولاء التي وحّدقم، فانسلكوا في

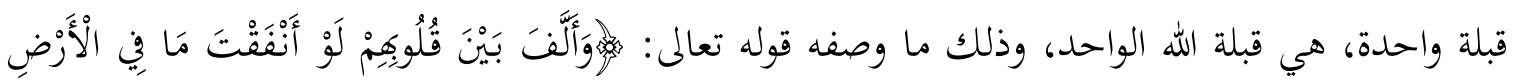

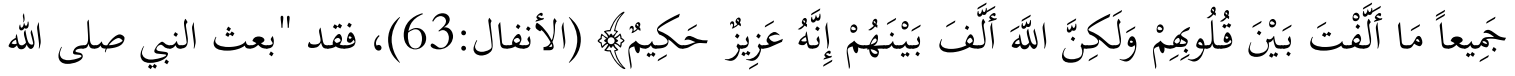
عليه وسلم إلى قوم أنففتُهم شديدة، وحميَّهم عظيمة، حتى لو لُطم رجل من قبيلة لطمة قاتل عنه أبناء قبيلته حتى يدركوا ثأره، ثُّ إغمم انقلبوا عن تلك الحالة حتى قاتل الرجل أخاه وأباه وابنه، واتفقوا على الطاعة وصاروا أنصاراً وعادوا أعواناً... فإزالة تلك العداوة الشديدة وتبديلها بالمحبة القوية والخالصة التامة هي مما لا يقدر 
عليها إلا الله تعالى"، 35 فهو الذي سلك القلوب المؤمنة به في سلك واحد، فابتهت إليه موحمّة الصفوف، ولو توزّعت وجهاةًا لانفرط عقد وحدةا، وآلت إلى الشتات.

إنّ هذه الوحدة في الولاء حطمت كل المقاييس في التفاضل بين الناس مما كان من قبل يرفع ويخفض، ويبعد ويقرّب، ويميّز بين الناس ويفرق بينهم، م عرق أو نسب، ومن جنس أو لون، ومن طبقة أو حرفة؛

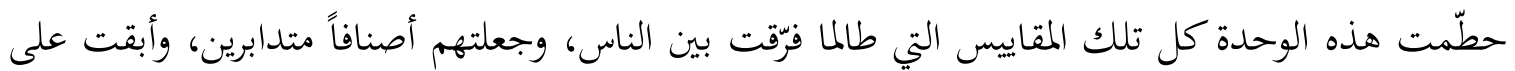
مقياس واحد يكون على أساسه التفاضل هو مقياس التقوى، أي مقدار الولاء لله ودرجته، فعلى أساسه

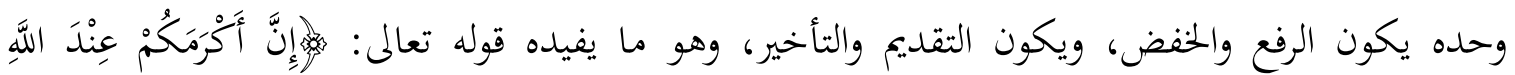
أَتَقَاكُمْهُ (الحجرات: 13). وليس هذا المقياس القائم على الولاء لله إلا حافزاً على وحدة الجماعة، إذ يحرص كل فرد منها على أن يكون مكرّماً فيها بما يُسسن من التقوى، وكلما كان الفرد أكثر إحساناً في الولاء لله كان أكثر تدعيماً لوحدة الجماعة.

ثالثاً - ـوحدة الغاية: إنّ الإيمان بالله من شأنه أن يوحّد الغاية بين المؤمنين، فكل مؤمن مهما كان بجال عمله في حياته إنما هو متوجّه في تفكيره وعمله نحو غاية واحدة هي عبادة اله تعالى، وابتغاء مرضاته بتحقيق الخلافة في الأرض، وعل تلك الغاية الموحّدة تلتقي كلّ المساعي من قِبَل الأفراد، فإذا بالجههود التي يبذلوها في التفكير وفي العمل جهود متجانسة سلكتها الغاية الموحّدة في سياق متوافق. ولو نظرنا في أسباب الفرقة بين الجماعات لألفينا من أهمّها اختلاف الغايات التي يتوجّه إليها الناس في أفكارهم وأعمالهم، فربَّ فردوٍ أو مجموعةٍ في نطاق المجتمع كانت غايةُ حياتم تحقيقَ الرّفاه المادّي بإشباع الشهوات المختلفة، فإذا بها جهودُهم في الفكر والسلوك تُسخَّر لتحقيق هذه الغاية بما تقتضيه من جشع وأنانية يدفعاها إلى جمع أكثر ما يمكن من أسباب الرّفاه إذ هو الغاية العليا، وهو ما يؤدّي إلى سلوك مسالك الهضيمة للآخرين، وذلك بالتسلّط عليهم والتحايل على ما في أيديهم، وهو ما يكون سبباً في الصراع والتدافع. وربَّ جماعة أخرى كانت غايتهم العليا حيازة السلطة والجاه بحيازة مواقع النفوذ، فإذا هم يسخّرون كلّ أعمالهم في تحصيل تلك الغاية بما يقتضيه من ضروب المغالطة التحايل حيناً، والتسلّط والقهر حيناً آخر، وهو ما يفضي أيضاً إلى لى

$$
\text { 35 }
$$


الصراع والتدابر؛ وقس على هذا كثيراً من الغايات القصيرة التي تختلف بين الجماعات في المجتمع الواحد أحياناً فتؤدي إلى الاصطراع والفرقة.

أما حينما تكون الغاية العليا هي ابتغاء مرضاة الله بتحقيق خلافته في الأرض، فإنّ كل الغايات القريبة التي تفرّق حينما تكون غايات هائية تصبح وسائل لتحقيق الغاية العليا، فإذا تحقيق الشهوات يكون في إطار منضبط بما يرضي الله في قواعد معينة تحكم تصرفات الناس، وتعصمهم من أن يتهافتوا عليها بما يؤدي إلى التدافع بينهم، وإذا مراكز السلطة والنفوذ تندرج هي الأخرى في سياق تحقيق العبودية لله، فلا تكون مركز جذب وتافت، إذ أوزارها بهذا الاعتبار تصبح أرجح من مغانهها، فلا يكون من أجلها صراع. وربما قيل فيما قرّرنا من اقتضاء الإيمان بالله تعالى لوحدة الغاية، واقتضائها بالتالي لوحدة الجماعة: إنّ تاريخ المسلمين وهم المؤمنون بالله تعالى حافل بالفرقة بين فرقهم وطوائفهم ومذاهبهم، ثم إنّ كثيراً من الأمم تبدو على قدر كبير من الوحدة الغائية رغم افتقارها إلى الإيمان بالله الذي هو سبب الوحدة الغائية كما قرّرنا، فكيف نشأت تلك الفرقة مع تحقق الإيمان بالله، وكيف تحققت هذه الوحدة مع فقدان ذلك الإيمان؟ والحقّ أنّ الافتراق في المجتمع الإسلامي كان له وجود في مختلف مراحل التاريخ، إلا أن بعض مظاهر ذلك الافتراق لا تعدّ في حقيقتها عند التأمل فيه افتراقاً، وإنما هو اختلاف في الرأي تتجه به الأطراف كلها نهو تحقيق الغاية الموحّدة، وذلك مثل الاختلاف في المذاهب الفقهية، والمذاهب العقديّة، فإنّ المفترقين فيها ما منهم إلا مبتغ وجه الله من خلال مذهبه، وقد كان في جهودهم العلمية التي أهت إليها مذاهبهم أكبر مظهر للوحدة؛ إذ ما من عنصر من عناصر علومهم إلا وهو محقق لغاية مرحلية تفضي إلى الغاية العليا، ولذلك فإن العلوم الإسلامية على كثرتا وتنوّعها لا تُرى إلا وحدة في المنهج والغاية مهما اختلفت الفرق التي تصدر عنها، وهو ما لا نظير له في أيّ ثقافة أخرى، ودع عنك في نطاق هذه الوحدة العامة تلك المشاحنات الصغيرة التي تتخللها أحياناً، فإنها طبيعة البشر مهما صفت بينهم الأخوة، وهي لم يكن لها ضرر يذكر في سياق الوحدة الثقافية العامة التي انصهرت فيها الطوائف الإسلامية على اختلافها.

وأما بعض مظاهر الافتراق الحقيقي الذي يقع بين المسلمين في بعض الأزمان، من مثل ما وقع من الحروب والفتن، ومن التنابذ الغليظ بين بعض الفرق أحياناً، فإنه لو حُحّلت أسبابه ودوافعه عند مقترفيه 
لأُلفيت راجعة إلى انخراف في الإيمان بالله طال بعض أركانه وأبعاده وخاصّة ركنه الرَّين المتعلّق بالإيمان بالوحدانية، فكانت الفُرقة إذن راجعة إلى ذلك الانخراف.

ومن أمثلة ذلك ما كان من عداء بين متطرّفة الشيعة وغلاة الصوفية من جهة والجمهور العام من المسلمين من جهة أخرى، وما كان من صراع دموي يدور بين طوائف سياسية من أجل الحكم، فإنّ سببه في الأول انحراف عقدي في الإيمان بالله صفاته، حيث كثيراً ما يقع أولئك المتطرفة وألغى في تصورات تناقض وحدانية الله تعالى من مثل تصوّرات الحلول والاتحاد وما يشبه تأليه الزعماء والمشايخ والرؤساء؛ وسببه في الثاني غفلة عن الله من فُظّاظ البدو وجهّالم في أطراف البلاد الإسلامية، أو سيطرة من الأهواء وشهوة السلطان وإرادة الثأر العصبي، وكلها تُتّخذ شركاء لله في الأتمار والانتهاء فتفضي إلى تناسيه غاية عليا، فتتعارض الغايات الصغرى من دونه، فإذا هو الصراع بين الطوائف المنتمية إلى الإسلام، ولكنّه انتماء غير قائم على الإيمان الحق بالله تعالى.

وأما ما يُرى من وحدة في بعض الأمم غير المؤمنة، فإنّه في حقيقته توّد ظاهري موقوت مشدود بمصالح ماديّة مشتركة، وإلا فإنه ينطوي على تناقضات داخلية صارخة لا تلبث أن تفجّر بين الحين والآخر، فإذا هو صراع شديد مدمّر كما بدا في الحربين العالميتين خلال النصف الأول من هذا القرن، وكما يبدو بين الحين والآخر تفككات قومية وحروب أهلية كثيرة.

إنّ الإيمان بالله يصنع بين معتنقيه رابطة وحدة قويّة تكون هي الأصل في العلاقة بينهم، وربما تعرض لهم عوارض من الفرقة سرعان ما يؤوبون منها إلى جوهر وحدقمم بما يتذكرون من وحدة الغاية. ولكنّ المجتمع غير المؤمن قد يتوحِّد بعوارض من المصالح المادية سريعاً ما تنصرم، فإذا هو الصراع والتدابر حالاً أصلية لذلك

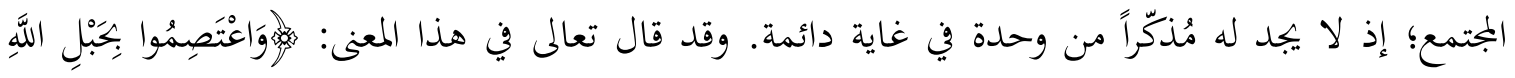

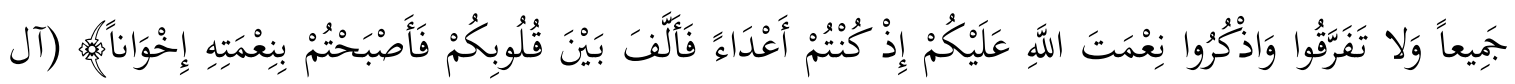
عمران: 103)، فليست هذه الوحدة بين المؤمنين إلا لتوحّدهم في الوجهة إلى الله، وليست الفرقة التي كانت تسودهم قبل إيماهم إلا لتشتت الغايات التي كانت لهم من دونه، وكذلك الأمر بالنسبة للناس في كل زمن، فكلما آمنوا بالله وأحسنوا في إيماهم توحّدوا بوحدة غايتهم إليه، وكلما ابتعدوا عن ذلك تفرّقت بهم الغايات 
فأصبحوا أشتاتاً. ولا يخفى أنّ أيّة أمة حينما تتوحّد غايتها، فإن ذلك يثمر رشداً في عملها، إذ تكون الجههود متجهة وجهة واحدة، وذلك ما يقوى به الدّفع في التحاه الإنجاز للأعمال الصالحة، فيكون من ذلك البناء الحضاري. أما حينما تتشتت الغايات، فإن الأعمال تتشتت هي أيضاً، وربما أصبحت متعارضة فيُحبط بعضها بعضاً، فإذا هو التوقف عن الإنجاز أو التقهقر إلى الوراء، وفي غضة المسلمين لما توحّدت غاياتم بالإيمان شاهد على الأول، وفي حال العرب في جاهليتهم شاهد على الثاني.

ب - تحرّر الجماعة: قد تنشأ في الجماعة قيود تتجاوز في مفعولها تقييد الإرادة الفردية في الفكر والحركة والفعل لتصيب الإرادة الجماعية في نزوعها إلى تحقيق مقتضيات الاجتماع في التعاون والسعي للإنجاز المشترك الذي به تزكو حياة المجتمع. وقد تكون تلك القيود داخلية المنشأ يصنعها التاريخ من موروثات الأسلاف، أو يصنعها التسلّط والاستبداد، وقد تكون خارجية تفرض على الجماعة من خارجها مثل الاستعمار بأشكاله المختلفة.

والإيمان بالله حقّ الإيمان كما يحرر الفرد في الفكر والإرادة، فإنّه يحرر الجماعة من كل القيود الداخلية والخارجية التي تعطّل الإرادة الجمعية والطاقات المشتركة فتعوقها عن الاندفاع في تحقيق الأهداف الجماعية التي من أجلها نشأت؛ وذلك لأنّ الإيمان بالله يقتضي الولاء الجماعي له، والاحتكام في كلّ شؤون الجماعة إليه، فلا يكن إذن بجال لارتمان الإرادة الجماعية إلا لإرادته، تحرراً من كل القيود المعطلة المتأتية من عوامل

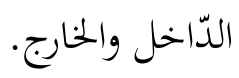

فالإيمان بالله يهرّر الجماعة من ربقة الممورث من الآباء والأجداد، ذلك الموروث الذي يترسّب بالتاريخ

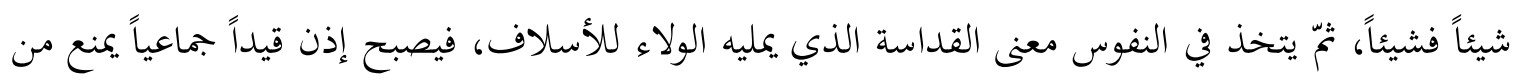
الانطلاق في تطوير الحياة بما تقتضي المعطيات الجلديدة التي تفرزها مُستأنفات الأوضاع. والإيمان بالله يجعل الجماعة متلقّية أصول حياتما من الله تعالى وحده، وهي أصول ينفسح فيها المجال لانتهاج الأساليب الناجعة في ممارسة الحياة الجماعية بما يفضي إلى ترقيه أن فلا تكون إذن مرتنة لتقاليد تستمدّ شرعيتها من الإرث لا من الحق والفعالية. وقد صوّر القرآن الكريم مراراً كيف أنّ انصراف الأمم عن الله الحقّ يوقعها في قيود الارتحان

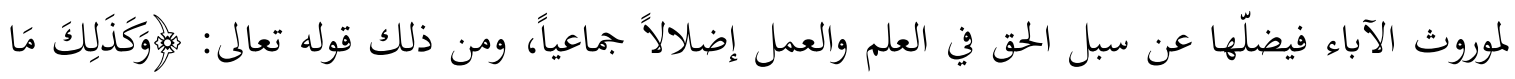




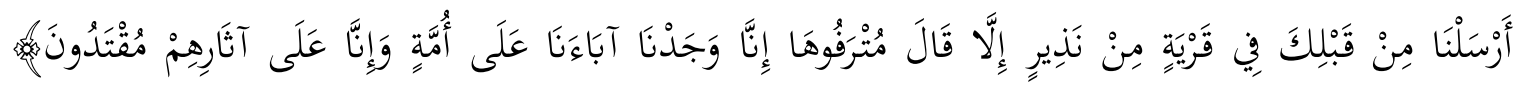

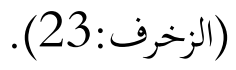

ويخرّر الإِمان بالله من الاستبداد السياسي الذي يتسلّط فيه فرد أو فئة على جمموع الأمّة في تديير

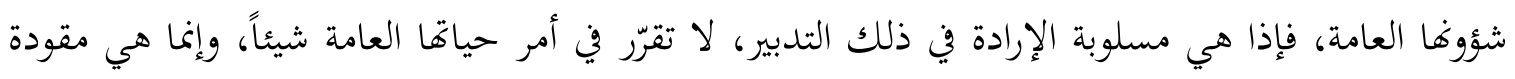
بإرادة ذلك الفرد أو تلك الفئة التي كثيراً ما تكون إرادة أهواء ومنافع خاصّة تضيع معها المصالح العامة.

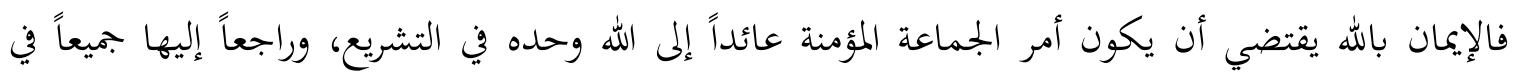

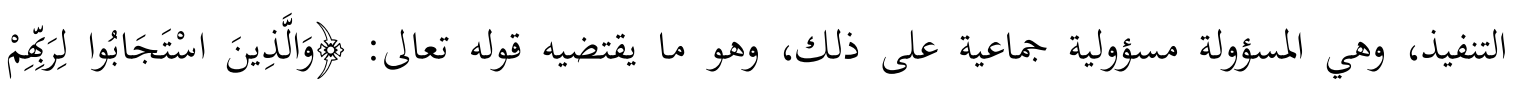

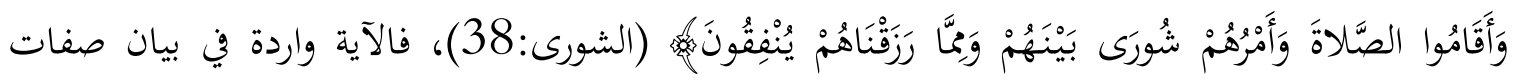
المؤمنين، وما يقتضيه إيمافم ذلك منهم؛ ومن بين مقتضيات إمياغم بالله أن يكون أمرهم في شؤون حياقم

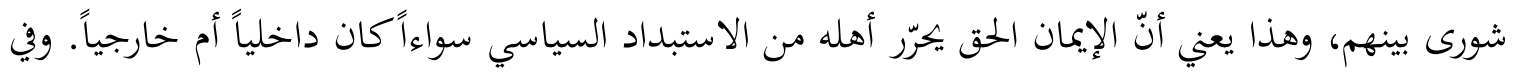

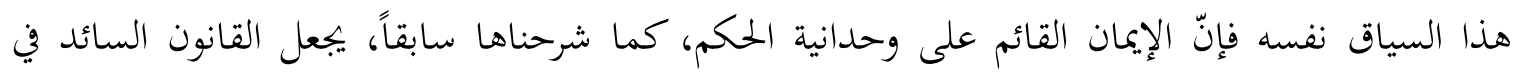

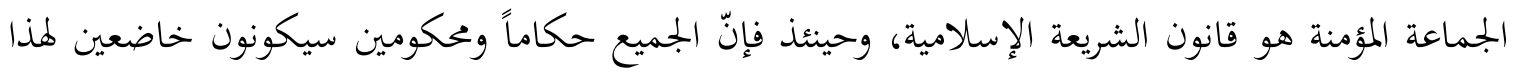

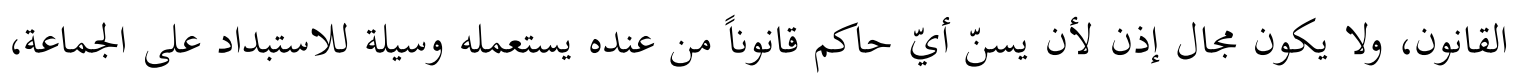

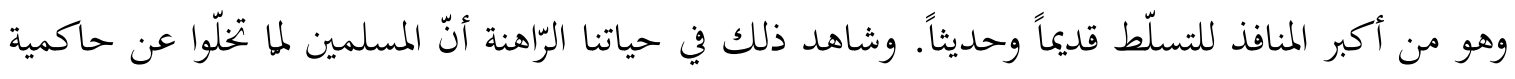

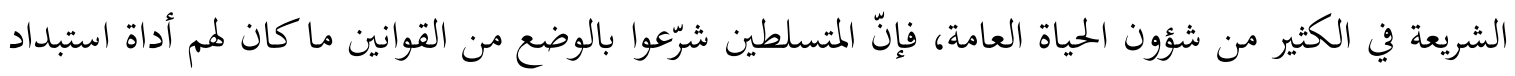

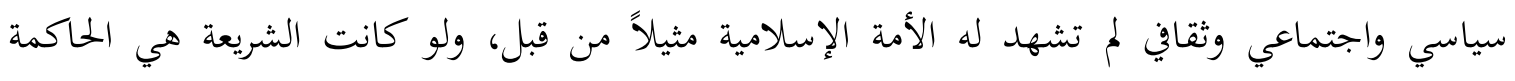

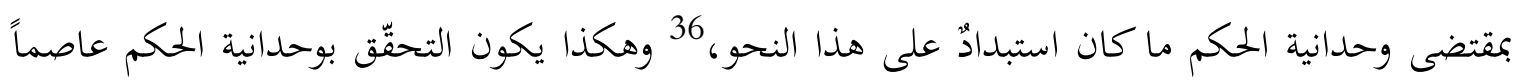

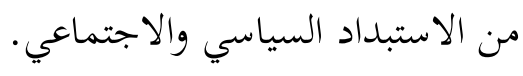
ويكرّر الإيمان بالله أيضاً من الاستبداد الاقتصادي الذي تخظى فيه الفئة القليلة من الناس بالثمرة الاقتصادية التي يشترك في إنتاجها الجمموع العام منهم؛ ذلك لأن الإميان بوحدانية الله تعالى يقتضي أن يكون

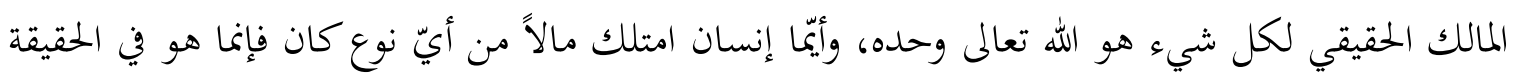

$$
\text { 36 بـ رابع: توفيق الشاوي: فقه الشورى والاستشارة (القاهرة: دار الوفاء، 1992)، ص413. }
$$


مؤتمن عليه ومستخلف فيه، فلا يحق له أن يتصرّف فيه إلا على الوجه الذي يأمر الله به من كسب حلال وإنفاق رشيد وسدّ لحاجات المحتاجين في المجتمع، فيؤدّي المال إذن وظيفة اجتماعية تحقق العدالة والكفاية، وينتفي فيها كلّ استبداد من فئة أو قلّة على كثرة، مهما يكن المستخلف فيه أفراداً أو فئات.

ولعلّ الاستبداد بالرّبا من أبشع الاستبداد الاقتصادي، كما هو جليّ في عصرنا الحاضر، حيث يُتِّذ

الرّبا وسيلة لرهن إرادة الشعوب الفقيرة من قِبل الأمم الغنية، فإذا هي مكبّلة اقتصادياً تلهث لتسدّد الفوائض الرّبوية التي تستغرق ثرواتما القومية، فلا يبقى بعد ذلك مال يستخدم لأغراض التنمية والنهضة. ويسبّب ذلك الارتان الاقتصادي ارتاناً سياسياً وثقافياً. وما يجري في هذا الشأن بين الأقوياء والضعفاء على صعيد الأمم، برك، يقع نظير له على صعيد الأفراد والمجاعات في نطاق الشعب الواحد؛ ولذلك قال تعالى في الرّبا قولاً غليظاً

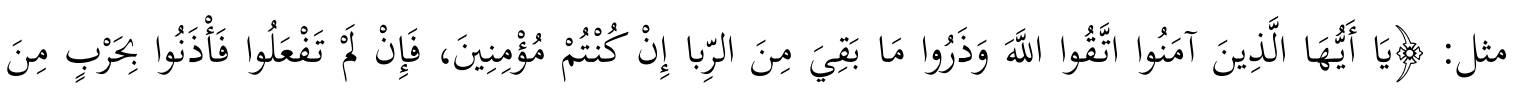
اللَّهِه. (البقرة:277-278)، فالإيمان بالله إذن يهرّر الجماعة المؤمنة من هذا اللّون القاسي من ألوان الاستبداد الاقتصادي.

والجماعة المؤمنة بالله يحرّرها إيماها أيضاً من كل ألوان الارتان الثقافي للأمم والجماعات الأخرى متمثلاً في التبعية الثقافية من حيث العادات والتقاليد وأنماط العيش، فهذا الارقان يجعل الأمة المرتنة تترسّ خطى من ارتهنت له، وينتج عن ذلك خمول في الفعالية والمبادرة والابتكار لضياع الشخصية الثقافية المفرزة لقوة الذات، كما ينتج عنه تبعية اقتصادية وسياسية أحياناً، فهو نوع من تقييد الإرادة الجماعية وإن يكن تقييداً غير ظاهر، ولكنّه يقّّص إلى حد بعيد الفعالية الاجتماعية، وذلك أمر تعيشه الأمة الإسلامية اليوم في كثير من أحواها؛ وما ذلك إلا لأنّ ولاءها لله تعالى شابه ضعف كبير، ولو كان هذا الولاء خالصاً لكانت كل الأنماط في الحياة، وكل العادات والتقاليد محكومة بأوامر الله ونواهيه مشتقة منها عند الإنشاء، وخاضعة

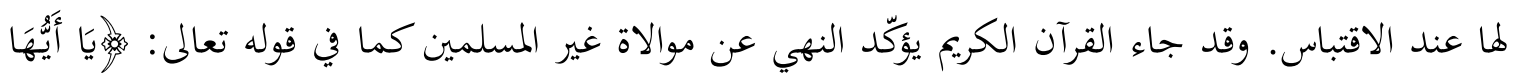

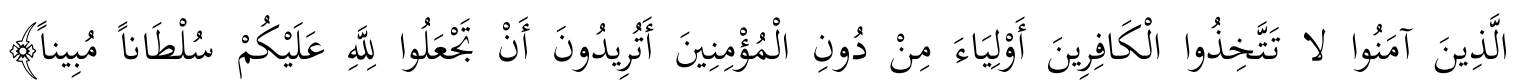
(النساء:144)، فاتِّاذ المؤمنين الكافرين أولياء مدخل من مداخل تسلّطهم عليهم تسلطاً ثقافياً في أقلّ تقدير، وتمحيض الولاء لله تعالى هو المحرّر من ذلك التسلط، إذ يكون السلطان له وحده في شؤون الحياة 
كلها، وذلك مندرج في ترير المؤمنين من الارتحان المعيق للفعالية الجماعية؛ إذ الموالاة تقتضي فيما تقتضي ضرباً من الخضوع، وهو إذا ما كان لمن يخالف في الوجهة يصبح مقيّداً لإرادة الجماعة في المضيّ إلى وجهتها الخاصة.

وقد كان للإيمان بالله أثثره الفعّال على صعيد الواقع في دفع الأمّة الإسلامية إلى الحركة التحرّرية لما حلّ هما الاستعمار من قِبل الشعوب الأوربية. فعلى الرغم من أنّ الإيمان الذي كانت متحققة به ليس هو الإيمان. الكامل لما شابه من الضعف والانحراف، إلا أنّ ما بقي منه في نفوس كان هو المُرّك الأساسي لنهضة المسلمين في مقاومة الاستعمار بالجهاد في سبيل الله، ولو لم يكن ذلك الإيمان يعمر القلوب ولو في حدّه الأدنى لبقيت الشعوب الإسلامية مرهنة للمستعمرين، بل لذابت هويتها إلى الأبد على غرار شعوب أخرى لم يكن لها هوية إيمانية مثل الشعوب التي كانت تسكن القارة الأمريكية. وإذا كان الارقان الثقافي والاقتصادي ما زال مكبّلاً لإرادة الأمة الإسلامية إلى اليوم، فما ذلك إلا لأنّ تحطيم هذا الارقان يستلزم درجة من الإيمان بالله هي غير حاصلة لديها اليوم، وهي أعلى من تلك الدرجة التي كانت بها مقاومة الاستعمار السياسي متمثلة في الجهاد الأكبر، في حين كانت مقاومة الاستعمار بالجهاد الأصغر.

ج - التكافل الاجتماعي: ومعناه التناصر بين أفراد المجتمع ليسدّ بعضهم حاجات بعض، ويُسنَد الضعفاء من الأقوياء، وكذلك التناصر بينهم في القيادة بأعباء العمل الصالح، فيقوّي القادرون منهم على ذلك الضعفاء فيه، حتى ينتهي الأمر بهذا وذاك إلى أن تكن الجماعة المؤمنة بريئة من سواقط الأفراد والفئات الذين يعيشون على هامش الحياة: حرماناً من كريم المعيشة، أو عطالة عن العمل الصالح، وينخرط الجميع في حقوق الكرامة والكفاية، وفي واجبات العمل والتعمير.

والإيمان بالله تعالى دافع لتحقيق هذا المعنى من التكافل الاجتماعي؛ ذلك لأنّ استشعار وحدانية الله في خلق الإنسان وتدبيره وتولّي مصيره، يثمر في النفس شعوراً بالأخوّة إزاء الناس جميعاً، وإزاء المؤمنين خاصة، فيكون المؤمن رائياً نفسه في الآخرين بما هم أخوة له في الإنسانية بصفة عامة، أو أخوة له في الله بصفة خاصة، فإذا ما يصيبهم كأنه يصيبه، فيهبّ لنصرقم مما قد يقعون فيه من مهانة وعجز وحرمان، وهي يشعر في نصرقم كأنما ينصر نفسه لما استقر فيه من معاني الأخوّة في الإنسانية وفي الله، وذلك هو معنى قوله 


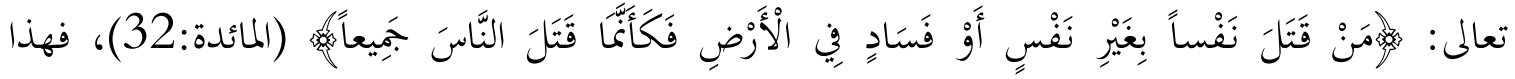
الامتداد الشعوري بإرادة الخير واستقباح اشر للناس جميعاً ن خلال الإرادة والاستقباح في حق إنسان واحد إنما هو متأتّ من الإيمان بالله المقتضي لتكريم الإنسان. 37 وذلك المعنى هو أيضاً ما جاء في قوله صلى الله عليه وسلم: "لا يؤمن أحدكم حتى يحب لأخيه ما يحب لنفسه"، 38 فهو الإيمان بالله الذي يجعل المؤمن يرى نفسه في الآخرين، ويرى الآخرين في نفسه، فيدفع ذك لا محالة إلى التكافل والتناصر.

ولو تدبّرنا القرآن الكريم لوجدنا أنّ تلك السور المكية الأولى نزولاً، التي جاءت تبشّر أساساً بوحدانية الله تعالى، وتدعو إلى الإيمان به الإيمان الحقّ، جاءت تقرن هذه الدعوة إلى الإيمان بالله بالدعوة إلى التكافل الاجتماعي: نصرة للضعفاء والمرومين من اليتامى والمساكين والعبيد والعجزة، وحفظاً لكرامتهم، وعوناً لهم على القيام بالعمل المثمر. 39 وقد ورد ذلك الاقتران مورد البيان لما يقتضيه الإيمان بالله من ذلك التكافل، وما يثمره من الدفع للقيام به، فكأنما هو بُعد مباشر من أبعاده، أو كأنّما هو وجه عملي له. ولهذه الثمرة من ثمار الإيمان مظاهر متعدّدة كما جاء في السياق القرآني.

فالإيمان بالله يقتضي التكافل النفسي المتمثّل في النصرة المعنوية لمن هم في انكسار نفسي بسبب أو بآخر من الأسباب، وقد جاء في القرآن الكريم تأكيد مكرّر لهذا المعنى فيما أولى من عناية باليتيم رمزاً لمنكسري النفوس، إذ قد ستجمع جميع معاني الانكسار النفسي، وذلك حينما جعل إكرام اليتيم ثمرة من ثمار الإيمان ببيان أنّ الشرك من آثاره الاستهانة باليتامى، والتنكّب عن نصرقم والبرّ بكم، وهو المفهوم من قوله

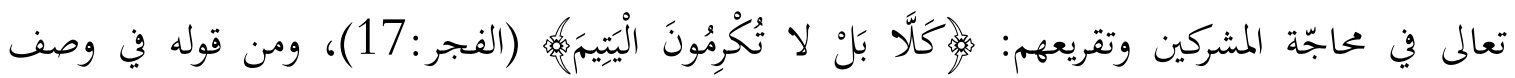

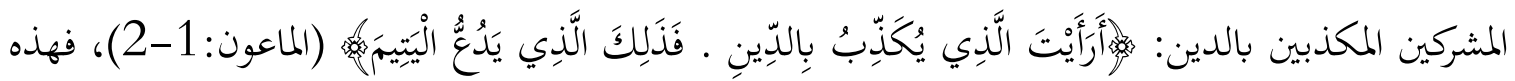
الآيات تفيد أنّ من يؤمن بالله حقّ الإيمان يكون مكرماً لليتيه، باراً به وناصراً له، وذلك مفهوم بطريق$$
37 \text { 3 }
$$$$
38
$$$$
\text { ذلك مثل ما ورد في سور: الفجر، والبلد، والماعون من حثثّ على فلكّ الرقبة، وإطعام المساكين، وإكرام اليتامى، وذلك في سياق }
$$ 
المخالفة، وهو عنوان للتناصر المعنوي النفسي بين المؤمنين بالله، ويندرج فيه أنواع التناصر المعنوي كافّة، مثل تفريج الكرب عن المكروبين، وإغاثة الملهوف، ونصرة المظلوم، وتحرير المستعبدين.

كما يقتضي الإيمان بالله التكافل الاقتصادي، وذلك بنصرة المحتاجين لمرافق الحياة، وتوفير حاجاقم منها، وقد جاء القرآن الكريم يؤَّد هذه النصرة، مبيّناً أغا من ثمار الإيمان، وأنّ الإخلال بها من ثمار الشرك، وذلك كما في قوله تعالى:

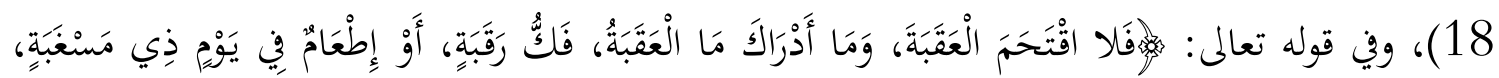

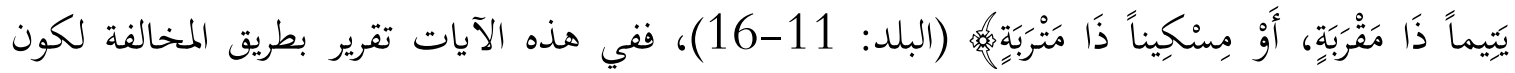
الإيمان بالله تعالى من شأنه أن يدفع المؤمن إلى كفالة إخوانه من المحرومين كفالة اقتصادية فضلاً عن الكفالة المعنوية بالتفريج النفسي، وذلك بييان أنّ من صفات المشركين الاستهتار بالضّعفاء والمحرومين، وقد أجمل هذا المعنى قوله صلى الله عليه وسلم: "ليس المؤمن الذين يشبع وجاره جائع"، 40 فمعناه أنّ الإيمان الحق بالله يثمر التكافل الاقتصادي بين المؤمنين تكافلاً يمتد إلى جميع ضرورات الحياة.

ويقتضي الإيمان بالله أيضاً التكافل الإنتاجي بين المؤمنين، وذلك بأن يمدّ المؤمن أخاه المؤمن بكلّ ما هو في حاجة إليه ليباشر به عملاً إنتاجياً، فيكون له بذلك عوناً على العمل الصالح. وقد جاء في القرآن المكّي ما يقرن الإمعان بالله بهذا المعنى التكافلي، وذلك في مثل قوله تعالى تشهيراً بالذي يكذّب بالدين:

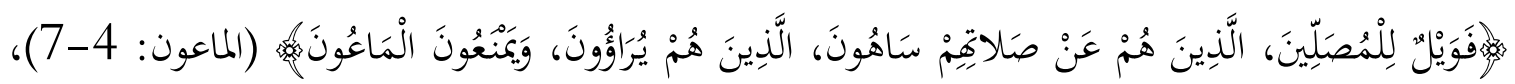
فلو كان هؤلاء مؤمنين بالله حقّ الإيمان لكانوا يتداولون الماعون الذي يستعان به على الأعمال المنزلية، وذلك رمز للآلات التي يستعان بها على ما هو أوسع من ذلك في بجال الإنتاج والتعمير.

إنّ طرح هذه القضايا التكافليّة المتنوّعة بين الجماعة المؤمنة في القرآن المكيّ -وهو الذي جاء يركّز أساساً على الدعوة إلى توحيد الله تعالى- لذو دلالة بالغة الأهمية على الارتباط بين حقيقة الإيمان بالله والتكافل الاجتماعي الذي تثمره تلك الحقيقة، وهو اتباط يجعل الإيمان بالله حقّ الإيمان يفضي بالجماعة المؤمنة إلى التكافل فيما بينها تكافلاً معنوياً نفسياً، وتكافلاً اقتصادياً، وتكافلاً إنتاجياً تعميرياً، وذلك ما لـ

$$
\text { 40 ب رواه البخاري في الأدب المفرد: باب لا يشبع دون جاره، رقم } 112 .
$$


تحقق على وجهه الأكمل في الجماعة الأولى التي آمنت بالله تعالى كما يبدو في التكافل بين الأنصار والمهاجرين في المجتمع الإسلامي الأول.

ومما يؤسف منه شديد الأسف ما آل إليه اليوم أمر المسلمين في أغلبهم من ضعف في التكافل الاجتماعي بينهم مما يقتضيه أصل الإيمان على النحو الذي بيّناه، وهو ضعف ليس بناشئ من تقصير عملي فحسب، وإنما هو ممتدّ في سببه إلى انحراف في تصوّر حقيقة التكافل نفسها من حيث هي بعد أساسي من أبعاد التوحيد كما بيّناه آنفاً، إذ أصبح يفهم عند الكثير من الناس على أنه من نوافل الدين، وأنهّ من باب التفضّل للقادرين على الكفالة لا من باب الفرض المرتبط بأصل الاعتقاد، وما ذلك إلا بسبب خلل في التصوّر الإيمان بالله تعالى، وحينما ينصلح ذلك التصور الإيماني ينصلح به التكافل الاجتماعي بين المسلمين ومن والاهم من الناس.

يتبيّن مما تقدّم كيف أنّ الإيمان بالله عامل فاعل يزكّي الجماعة المؤمنة كما يزّكي الفرد المؤمن، ويرقيّها في سبل النماء والخير والتعمير: توحيداً لها في الشعور والولاء والغاية، وتحريراً لها من معيقات الفعالية الاجتماعية، وتيسيراً للتكافل بينها في تحقيق الكرامة والاندفاع للعمل المثمر، وذلك ما وصفه أحد المفكرين في تركيز بليغ حين قال: "المؤمن يستشعر بعض الحاد مع سائر البشر؛ لأفم رفقاؤه في الخلق والقدر والمصير،

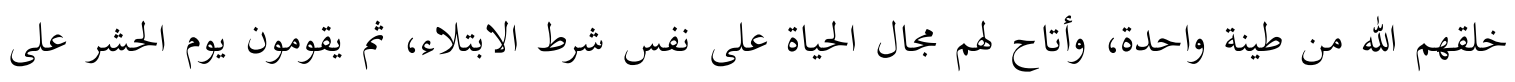
موقف سواء، ويحس المؤمن بإخاء أوثق نهو المؤمنين لأفم -بعد رفاقه البشر - أجمعوا على إرادة الإيمان، فقصدهم كلهم لقاء الله، وهُمهم عبادته وفجهم شريعته. ويحد المؤمن مناط تكليفه وقاعدة مسؤوليته في علاقاته بالمؤمنين، ويلفي في التعاون معهم سبباً للترقي بقدر عبادته إذ يعالجون معاً ما لا يتم إلا بالمشاركة، ويدركون ما لا يتيسّر إلا بالاتحاد. وكيفما تقلّب المؤمن في سيرته وعمله وافق سنّة المؤمنين كافة لأفم يهتدون بشريعة واحدة تأمرهم بذات وجوه البر، وتنهاهم عن المنكرات، ويجتكمون إلهيا فتفصل بينهم بالعدل المرضي". 
إنّ ما شرحناه من أثر للإِيمان بالله تعالى في حياة الإنسان، إنما هو متعلق بالإيمان الحي الواعي الذي تنفعل به النفس بما هو متمكّن منها تمكّن اليقين، وأما ذلك الإيمان الذي هو حال مبهمة من الانفعال بموجود غير مادّي، لا تتميّز فيه خطوط بيّنة، ولا تظهر فيه وحدانية جلية في أبعادها المتعددة، أو ذلك الإيمان الذي هو تقليد وراثي لا يكون فيه لله تعالى شهود واع في النفس، وإنما هي ترديدات لأقوال، وأداء لطقوس، وانسياق عامّ في موكب المسلمين دون تحقق فردي حي، فإنه إيمان لا يثمر من الآثار العملية في الحياة ما وصفنا، سواء في ذات الفرد أو علاقات المجتمع، بل هو يقصر عن ذلك بمقدار ما يقترب أو يبتعد عن صورة الإيمان الحقّ الذي شرحناه.

وإذا كان المؤمنون بالله من المسلمين قد أجدبت حياهم في تقض الأزمان ومنها الزمن الذي نعيشه من تلك الآثار العملية الفردية والاجتماعية في كثير منها أو قليل، فإنما مردّه إلى أن إيماغم بالله ينحط عن درجة الحق المطلوب، وبقدر ما يكون انخطاطه يكون إجداب حياقم من ثماره العملية. ولكن المؤمنين بالله متى ما عاودهم الوعي فقوي في نفوسهم الحضور الإلهي بعد خفوت، وتحققوا بالله تعالى تحققاً شاملاً بعد غفلة وانحراف تصوّر، فإهم لا يلبثون أن يروا الفعالية المثمرة تدبّ في حياتم المجدبة، فإذا هي تنمو في التحاه التحضّر بنمو وعيهم وتحقهم بالله، وهل أيلولة حياة أهل الجاهلية من العرب وغيرهم إلى الازدهار بعد الضحالة لما آمنوا بالله إلا شاهد على ذلك؟ وهل انصلاح حياة المسلمين بأثر من انصلاح إيمافم بأثر دعوات المصلحين والمجددين بين الحين والآخر من تاريخهم، وانقلابها من الضعف إلى القوة إلا أمثلة على

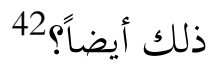

وما شرحناه في هذا البحث من آثار عمليّة تترتبّ على الإيمان بالله، وتثمر في الحياة الفردية والاجتماعية رشداً ونماء، نوجّهه في هذا المقام وجهة المعارضة لتلك المقولة التي لها غلبة في ثقافة أهل الغرب، وطالت بعض ناشئة الأمة الإسلامية افتتاناً بالوضع الحضاري الغربي المسيطر، وهي أنّ الإيمان بالغيب وعلى رأسه الإيمان بالله تعالى من شأنه أن يعطّل في الإنسان فرداً وجماعة عوامل الفعالية، ويكبّله بأسباب من الحمول والارتمان لعالم الغيب ينحسر به عن ممارسة الحياة العملية المثمرة، وينأى به عن غشيان خضمّ الحياة 
الاجتماعية، وعن اقتحام الكون لاستثمار مرافقه المختلفة، ليركن إلى العزلة والخلوص لتصوّرات الغيب، نشداناً للخلاص الفردي، وسعياً إلى السعادة المطلقة بالعمل على الالتحاق بعالم الغيب والفناء فيه، والإدبار عن عالم الشهادة وما يقتضيه من العمل. إنّ هذه المقولة إذا كان لها بعض المبرّرات في انطلاقها من مشاهدة الإيمان في بعض الأديان المنحرفة كما كانت سائدة في المجال الظريف الذي نشأت فيه، أو من مشاهدة التديّن عند بعض الفرق المنحرفة المنتسبة إلى الإسلام، فإنّا ليس لها من مبرّ على الإطلاق في أن تُسحب على الإيمان بالله كما رسمته العقيدة الإسلامية، فذلك إممان مخالف لما في الأديان الأخرى كلها، وهو مخالف لما تدّعيه بعض الفرق المنحرفة التي تنتسب إلى الإسلام. إنه إيمان قوامه التوحيد المطلق، وهو يقوم على اعتبار أن الفعل الحضاري في عالم الغيب فيه يتوقف في سعادته وشقائه على ما يكون من تعمير حضاري في عالم الشهادة؛ ولذلك فإنه إذا ما تحمّلته النفس حقّ التحمل لا يكون له في الحياة العملية إلا الآثار المثمرة للترقي الفردي والجماعي مادياً وروحياً، والشاهد على ذلك تاريخ عريض من الحضارة الإسلامية المزدهرة في المادة والروح معاً، وهو شاهد واقعي يدعّمه التحليل المنطقي الذي يربط الأسباب بالنتائج على النحو الذي شرحناه في هذا البحث.

وننبه في الختام إلى أنّ ما شرحناه في هذا البحث إنما هو الآثار العملية للإيمان بالله في هذه الحياة

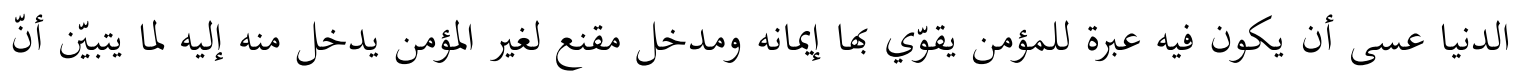
فيه مبتغاه من السعادة والأمن وهو ما لم يحصّله في حياة الجحود والكفران. وأما آثار هذا الإيمان في الآخرة

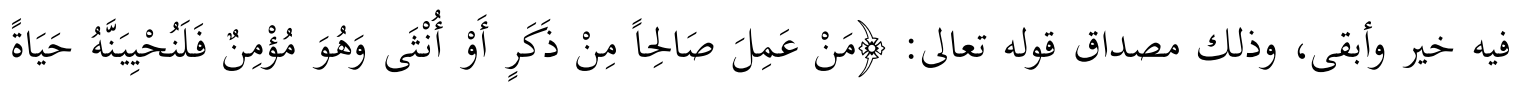

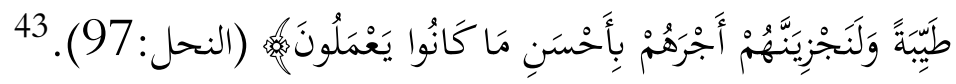

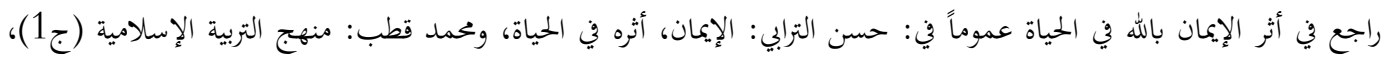

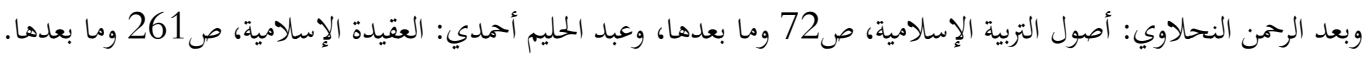

